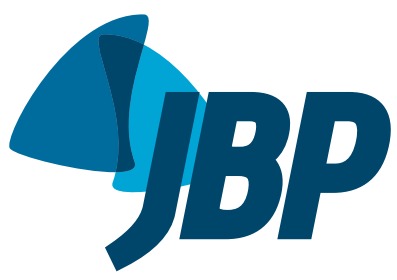

1. Hospital de Messejana Dr. Carlos Alberto Studart, Fortaleza (CE) Brasil.

2. Núcleo de Estudos e Tratamento do Tabagismo, Instituto de Doenças do Tórax Universidade Federal do Rio de Janeiro UFRJ - Rio de Janeiro (RJ) Brasil.

3. Escola de Medicina. Pontifícia Universidade Católica do Rio Grande do Sul - PUCRS Porto Alegre (RS) Brasil.

4. Disciplina de Pneumologia, Faculdade de Medicina de Botucatu, Universidade Estadual Paulista - UNESP - Botucatu (SP) Brasil.

5. Hospital das Clínicas, Universidade Federal de Minas Gerais, Belo Horizonte (MG) Bras

6. Hospital do Servidor Público Estadual de São Paulo, São Paulo (SP) Brasil.

7. Instituto Nacional de Pesquisas Espaciais, São José dos Campos (SP) Brasil.

8. Pavilhão Pereira Filho da Santa Casa, Faculdade de Medicina, Universidade Federal do Rio Grande do Sul, Porto Alegre (RS) Brasil.

9. Instituto Nacional de Câncer José Alencar Gomes da Silva, Rio de Janeiro (RJ) Brasil.

10. Faculdade de Medicina, Universidade Estácio de Sá, Rio de Janeiro, (RJ), Brasil.

11. Instituto Estadual de Doenças do Tórax Ary Parreiras - IETAP - Secretaria Estadual de Saúde do Rio de Janeiro, Niterói (RJ) Brasil.

12. Faculdade de Medicina, Universidade Federal de Mato Grosso, Cuiabá (MT) Brasil.

13. Centro Universitário de Várzea Grande UNIVAG - Várzea Grande (MT) Brasil.

14. Divisão de Pneumologia, Instituto do Coração - InCor - Hospital das Clínicas. Faculdade de Medicina, Universidade de São Paulo, São Paulo (SP) Brasil.

15. Faculdade de Medicina, Universidade de Brasilia, Brasilia (DF) Brasil.

16. Escola Bahiana de Medicina e Saúde Pública, Salvador (BA) Brasil.

17. Escola de Medicina, Universidade Federal de Ouro Preto, Ouro Preto (MG) Brasil.

18. Hospital Conceição, Porto Alegre (RS) Brasil.

19. Secretaria de Saúde do Paraná - SESAPR - Curitiba (PR) Brasil.

20. Secretaria de Saúde do Distrito Federal SESA-PR - Brasília (DF) Brasil.

Submitted: 1 October 2018 Accepted: 29 October 2018.

Study carried out in the Hospital de

Messejana Dr. Carlos Alberto Studart, Fortaleza (CE) Brasil.

\section{Update on the approach to smoking in patients with respiratory diseases}

\author{
Maria Penha Uchoa Sales ${ }^{1, a}$, Alberto José de Araújo ${ }^{2, b}$, José Miguel Chatkin ${ }^{3, c}$, \\ Irma de Godoy ${ }^{4, \mathrm{~d}}$, Luiz Fernando Ferreira Pereira ${ }^{5, \mathrm{e}}$, \\ Maria Vera Cruz de Oliveira Castellano ${ }^{6, f}$, Suzana Erico Tanni ${ }^{4,9}$, \\ Adriana Ávila de Almeida ${ }^{7, h}$, Gustavo Chatkin ${ }^{3, i}$, Luiz Carlos Côrrea da Silva ${ }^{8, j}$, \\ Cristina Maria Cantarino Gonçalves ${ }^{9, k}$, Clóvis Botelho ${ }^{12,13,1}$, \\ Ubiratan Paula Santos ${ }^{14, m}$, Carlos Alberto de Assis Viegas ${ }^{15, \mathrm{n}}$, \\ Maristela Rodrigues Sestelo ${ }^{16,0}$, Ricardo Henrique Sampaio Meireles ${ }^{10,11, p}$, \\ Paulo César Rodrigues Pinto Correa ${ }^{17, q}$, Maria Eunice Moraes de Oliveira ${ }^{18, r}$, \\ Jonatas Reichert ${ }^{19,5}$, Mariana Silva Lima ${ }^{6, t}$, Celso Antonio Rodrigues da Silva ${ }^{20,4}$
}

\section{ABSTRACT}

Smoking is the leading cause of respiratory disease (RD). The harmful effects of smoking on the respiratory system begin in utero and influence immune responses throughout childhood and adult life. In comparison with "healthy" smokers, smokers with RD have peculiarities that can impede smoking cessation, such as a higher level of nicotine dependence; nicotine withdrawal; higher levels of exhaled carbon monoxide; low motivation and low self-efficacy; greater concern about weight gain; and a high prevalence of anxiety and depression. In addition, they require more intensive, prolonged treatment. It is always necessary to educate such individuals about the fact that quitting smoking is the only measure that will reduce the progression of RD and improve their quality of life, regardless of the duration and severity of the disease. Physicians should always offer smoking cessation treatment. Outpatient or inpatient smoking cessation treatment should be multidisciplinary, based on behavioral interventions and pharmacotherapy. It will thus be more effective and cost-effective, doubling the chances of success.

Keywords: Respiratory tract diseases/therapy; Respiratory tract diseases/drug therapy; Tobacco use disorder/epidemiology; Smoking cessation; Counseling; Lung neoplasms.

\section{INTRODUCTION}

Smoking is the leading cause of preventable death worldwide, annually accounting for 7 million deaths, 890,000 of which are associated with passive smoking. ${ }^{(1)}$ In Brazil, 156,000 people die each year from smoking-related diseases. (2) Worldwide, there are approximately 1.1 billion smokers, most of whom live in low- and middleincome countries, where the morbidity and mortality burden of smoking is higher. ${ }^{(1)}$

The prevalence of smoking in Brazil has dropped significantly, as evidenced in the 2006-2017 historical series of the Brazilian "Telephone-based System for the Surveillance of Risk and Protective Factors for Chronic Noncommunicable Diseases Survey", which showed that the prevalence fell from $19.5 \%$ to $10.1 \%$, translating to a $48.2 \%$ reduction. ${ }^{(3)}$ The survey showed that, although smokers accounted for only $10.1 \%$ of general population in 2017 (13.2\% of the male population and $7.5 \%$ of the female population), there were still 18.2 million smokers $\geq 18$ years of age in that year. ${ }^{(3,4)}$

The Framework Convention on Tobacco Control ${ }^{(5)}$ lists offering smoking cessation treatment as one of the six most cost-effective policies in the MPOWER package, the acronym MPOWER standing for Monitoring tobacco use and prevention policies; Protecting people from tobacco smoke; Offering help to quit tobacco use; Warning about the dangers of tobacco; Enforcing bans on tobacco advertising, promotion and

Correspondence to:

Maria da Penha Uchoa Sales. Rua Gothardo Moraes, 155/1002A, CEP 60177-340, Fortaleza, CE, Brasil.

Tel.: 5585 99909-8728. E-mail: puchoasales152@gmail.com

Financial support: None.

a. (iD) http://orcid.org/0000-0002-4226-6216; b. (iD) http://orcid.org/0000-0001-7159-1395; c.

d. ip http://orcid org/0000-0002-6588-5626;

g. (iD) http://orcid.org/0000-0002-2587-2759; $h$. http://orcid.org/0000-0002-1377-2072; f.

http://orcid.org/0000-0003-3226-8231; i. http://orcid.org/0000-0002-1299-0596; I.

http://orcid.org/0000-0002-4343-025X

(iD http://orcid.org/0000-0003-2964-1453; k.

(iD) $h+1 \mathrm{p} / / 0 \mathrm{rcid}$.

m. (iD) http://orcid.org/ 0000-0003-4919-884X; n.

http://orcid.org/0000-0002-0801-6299; 0.

(iD) $h t t p: / / o r c i d . o r g / 0000-0003-0961-4474$

p. iD http://orcid.org/0000-0002-9916-2987; q.

http://orcid.org/0000-0001-7108-0640; r.

http://orcid.org/0000-0003-4461-7582;

http://orcid.org/0000-0002-5438-3428; u

http://orcid.org/0000-0003-4012-8220;

http://orcid.org/0000-0001-8842-5393 
sponsorship; and Raising taxes on tobacco. ${ }^{(6)}$ Despite the success of anti-smoking policies in Brazil, including the fact that smoking cessation treatment is offered via the Brazilian Unified Health Care System, ${ }^{(7,8)}$ there are subgroups of smokers with relevant comorbidities who have greater difficulty in quitting smoking, such as patients with COPD, which requires additional efforts to offer smoking cessation treatment and devise strategies for smoking cessation programs. ${ }^{(9)}$

Smokers with chronic noncommunicable diseases related to smoking need to be treated with maximum efficacy because, if they continue to smoke, the progression of those diseases will have enormous consequences for their lives, including early disability and premature death. $(10,11)$

The approach to smoking cessation should be directed toward effecting behavioral changes, creating motivation, and instilling the desire to avoid the triggers of cravings, supported by effective pharmacotherapy, as recommended in the main guidelines. ${ }^{(12-14)}$ Physicians should be prepared to provide smoking cessation treatment, patients with chronic lung diseases requiring special attention.

This article had a number of objectives. In addition to reviewing and evaluating the main evidence regarding the health effects of smoking on respiratory diseases, we aimed to alert physicians (pulmonologists in particular) to the fact that smoking cessation should be prioritized in the treatment of lung diseases. ${ }^{(8,15,16)}$

\section{METHODOLOGY}

The chosen search strategy was the method known as integrative review, the purpose of which is to perform keyword searches, as well as to gather articles, systematic reviews, and technical reports, in order to summarize the results and evidence regarding a specific theme. ${ }^{(17-19)}$

For the present review, the following research questions were formulated:

- What is the evidence regarding smoking cessation counseling in patients with respiratory diseases?

- What is the evidence regarding smoking cessation pharmacotherapy in patients with respiratory diseases?

From the results of online searches of the Brazilian Virtual Health Library, SciELO, and MEDLINE/PubMed databases, we selected 176 articles. We used the following search terms (keywords): smoking; nicotine dependence; effects on respiratory health; pharmacotherapy on cessation; cessation counseling; chronic obstructive pulmonary disease; asthma; tuberculosis; and pneumoconiosis.

\section{CLINICAL EVALUATION OF SMOKERS}

Smokers with respiratory diseases have a greater need and urgency to quit smoking; therefore, physicians need to take a proactive role in encouraging such patients to give up the habit and offering smoking cessation treatment. This approach should be taken in conjunction with the treatment of the underlying disease. Therefore, physicians need to be trained not only in the management of the smoking cessation pharmacotherapy but also in cognitive-behavioral therapy techniques. ${ }^{(13,15)}$

From the first visit, the physician should inform the patient of the fact that quitting smoking is the only measure that will slow the decline in lung function, improve the response to treatment, and reduce the frequency of exacerbations. The approach should be multidisciplinary and should be applied at all levels of health care, for outpatients and inpatients. ${ }^{(20,21)}$

Smokers with respiratory diseases have peculiarities that can hinder smoking cessation, such as a higher level of nicotine dependence and withdrawal symptoms that are more severe; low motivation; low self-efficacy; excessive concern about weight gain; and a high prevalence of psychiatric disorders. In addition, they require treatment that is more intensive and prolonged. ${ }^{(21,22)}$

Identifying the predictive factors and knowing the techniques for achieving smoking cessation are fundamental to the approach to smokers. The level of motivation is predictive of the frequency of attempts to quit smoking, and the level of nicotine dependence is predictive of the outcomes of those attempts. The concomitant use of alcohol or drugs can make smoking cessation more difficult. ${ }^{(23,24)}$

Before starting treatment, smokers should undergo a full clinical evaluation, as detailed in Chart 1. . $^{(10,13)}$ The objectives of the anamnesis include analyzing the smoking habits of patients, as well as their level of motivation, dependence, and self-efficacy, together with their experience in previous attempts at smoking cessation, their history of smoking-related diseases, contraindications for specific medications, their beliefs, and their preferences. ${ }^{(10,25)}$ The physician should perform a complete physical examination and order ancillary tests, depending on the local demand and availability. ${ }^{(23)}$ Spirometry and imaging findings can be useful in motivating such patients to quit smoking. . $^{(24,26,27)}$

Knowing the level of nicotine dependence is important to guide the treatment (Chart 2). The most widely used instrument is the Fagerström Test for Nicotine Dependence. ${ }^{(28)}$ In 2012, it was renamed the Fagerström Test for Cigarette Dependence. ${ }^{(29)}$ The instrument most widely used in assessing the level of motivation for quitting smoking is the transtheoretical model of change developed by Prochaska \& DiClemente, ${ }^{(30)}$ which is useful for developing a smoking cessation plan (Chart 3).

\section{CURRENT EVIDENCE REGARDING THE EFFECTIVENESS OF COUNSELING AND PHARMACOTHERAPY}

\section{Cognitive-behavioral counseling}

After identifying the level of nicotine dependence for each patient, the main subsequent step is a brief 
Chart 1. Smoking anamnesis and initial clinical examination: what to value?

\begin{tabular}{|c|c|}
\hline Smoking history & Information to be collected and tests to be performed \\
\hline $\begin{array}{l}\text { Age at smoking onset and smoking } \\
\text { intensity }\end{array}$ & $\begin{array}{l}\text { Age at onset of regular smoking; number of cigarettes/day; frequency of use; } \\
\text { and total smoking history, in pack-years }\end{array}$ \\
\hline Forms of nicotine use & $\begin{array}{l}\text { Conventional cigarettes; hand-rolled cigarettes; clove cigarettes; chewing } \\
\text { tobacco; snuff, hookah; e-cigarettes; heat-not-burn tobacco products; } \\
\text { cigars; and pipes }\end{array}$ \\
\hline $\begin{array}{l}\text { Attempts, treatments, abstinence and } \\
\text { outcomes }\end{array}$ & $\begin{array}{l}\text { Number of attempts and previous treatments, with or without success; } \\
\text { withdrawal symptoms; and relapse and probable causes }\end{array}$ \\
\hline Associated factors: smoking triggers & $\begin{array}{l}\text { Behavioral (coffee, alcoholic drink, after meals, driving, etc.); emotional } \\
\text { (stress, argument, anxiety, depression, etc.); and environmental (living with } \\
\text { smokers at home, at work, or during leisure) }\end{array}$ \\
\hline Passive smoking & Passive smoking: secondary and tertiary \\
\hline Level of dependence & Fagerström Test for Nicotine Dependence \\
\hline Level of motivation & $\begin{array}{l}\text { Motivational stage: Prochaska \& DiClementi model; and self-efficacy scale: } \\
\text { readiness, importance, and trust }\end{array}$ \\
\hline Evaluation of anxiety and depression & $\begin{array}{l}\text { Hospital Anxiety and Depression Scale; Beck Anxiety Inventory; and Beck } \\
\text { Depression Inventory }\end{array}$ \\
\hline $\begin{array}{l}\text { Clinical comorbidities that alter the } \\
\text { course or management of treatment }\end{array}$ & $\begin{array}{l}\text { Oral lesions; peptic ulcer; diabetes; hypertension; heart diseases; lung } \\
\text { diseases; nephropathy; liver disease; cancer; history of convulsion; epilepsy; } \\
\text { stroke; allergies (cutaneous, respiratory, and drug-related); and skin } \\
\text { disorders }\end{array}$ \\
\hline $\begin{array}{l}\text { Psychiatric comorbidities that alter the } \\
\text { course or management of treatment }\end{array}$ & $\begin{array}{l}\text { Anxiety; depression; bipolar disorder; panic disorder; schizophrenia; } \\
\text { attention-deficit/hyperactivity disorder; anorexia nervosa; bulimia; and } \\
\text { impulse control disorders (food, shopping, pathological gambling) }\end{array}$ \\
\hline $\begin{array}{l}\text { Consumption of alcohol or other } \\
\text { psychoactive substances }\end{array}$ & $\begin{array}{l}\text { CAGE questionnaire; AUDIT; pattern of alcohol use; recent alcohol } \\
\text { withdrawal; and pattern of use of marijuana, crack cocaine, and other drugs }\end{array}$ \\
\hline Physical activity and body weight & Regular physical activity; sedentary lifestyle; and body mass index \\
\hline Medications that can affect treatment & $\begin{array}{l}\text { Antidepressants; MAO inhibitors; carbamazepine; phenytoin; barbiturates; } \\
\text { antipsychotics; cimetidine; pseudoephedrine; oral hypoglycemic agents; } \\
\text { insulin; systemic corticosteroids; and theophylline }\end{array}$ \\
\hline $\begin{array}{l}\text { Individuals/situations that call for } \\
\text { caution in the use of drugs }\end{array}$ & $\begin{array}{l}\text { Adolescents; pregnant or breastfeeding women; the elderly; recent cases of } \\
\text { acute myocardial infarction or stroke; severe arrhythmia; use of psychotropic } \\
\text { drugs; and chronic renal failure (hemodialysis) }\end{array}$ \\
\hline Family history & History of smoking in family members; cohabitation with smokers \\
\hline Physical examination & $\begin{array}{l}\text { Complete physical examination, identifying previous or current } \\
\text { symptomatology, limited to the therapeutic protocol to be proposed }\end{array}$ \\
\hline Ancillary tests & $\begin{array}{l}\text { Basic routine: chest X-ray; spirometry; electrocardiogram; complete blood } \\
\text { count; and serum/urine biochemistry; and useful tests in the evaluation and } \\
\text { follow-up: exhaled carbon monoxide and cotinine level (in serum, saliva, or } \\
\text { urine) }\end{array}$ \\
\hline
\end{tabular}

Based on data from Reichert et al.(12) and Fiore et al.(13) CAGE: Cut down, Annoyed, Guilty, and Eye-opener; AUDIT: Alcohol Use Disorders Identification Test; and MAO: monoamine oxidase.

counseling session for smoking cessation and the scheduling of follow-up visits with longer sessions. ${ }^{(31)}$

It is known that self-efficacy and self-esteem affect the capacity of an individual to quit smoking; therefore, constructive advice should be directed at addressing issues related to the level of motivation to quit smoking and to remain abstinent. (31) Whenever possible, the physician should individualize smoking cessation treatment, discussing the relationship that the individual has with the smoking habit and the reasons why the individual continues to smoke, as well as the therapeutic options available in terms of psychological and pharmacological support. ${ }^{(10,13)}$

In the initial counseling sessions, the physician should be empathetic and should be aware of smoking cessation strategies, in order to help the smoker through this early stage. The negative effects of smoking and the benefits of smoking cessation should be addressed. ${ }^{(31)}$ In the treatment protocol, it is essential to establish a date of cessation; to identify situations in which the risk of relapse is high and teach the skills required in order to cope with them; to explain the withdrawal symptoms; and to follow the patient closely through physician consultations, telephone calls, e-mails, WhatsApp messages, and text messages. ${ }^{(23,30,31)}$ The physician should educate the patient regarding the potential complications of treatment and benefits of quitting smoking. In addition, minimizing fatalistic beliefs and addressing depression improve self-efficacy, self-esteem, and the feeling of having control over the treatment. ${ }^{(31)}$

In patients with asthma or COPD, it is possible to increase the level of motivation by contextualizing the results of spirometry. ${ }^{(24,26,27)}$ In patients with lung 
Chart 2. Evaluation of the level dependence: Fagerström Test for Nicotine Dependence.

1. How soon after you wake up do you smoke your first cigarette?
(3) $\leq 5 \mathrm{~min}$
(2) 6-30 min
(1) $31-60 \mathrm{~min}$
(0) $>60 \mathrm{~min}$

2. Do you find it difficult to refrain from smoking in places where it is forbidden?
(1) Yes
(0) No

3. Which cigarette would you hate most to give up?
(1) The first one in the morning
(0) Any other

4. How many cigarettes do you smoke per day?
$(0) \leq 10$
(1) $11-20$
(2) $21-30$
(3) $\geq 31$

5. Do you smoke more frequently during the first hours after waking than during the rest of the day?
(1) Yes
(0) No

6. Do you smoke when you are so ill that you are in bed most of the day?

(1) Yes

(0) No

Total score: $0-2=$ very low; $3-4=$ low; 5 = average; $6-7=$ high; and 8-10 = very high.

Adapted from Heatherton et al. ${ }^{(28}$

Chart 3. Stages of behavioral change.

\begin{tabular}{|ll|}
\hline \multicolumn{1}{c}{ Stage } & \multicolumn{1}{c|}{ Description of the stage and motivational counseling strategies } \\
Precontemplation & $\begin{array}{l}\text { There is no intention to stop in the foreseeable future (next } 6 \text { months); nor is } \\
\text { there even the realization that the smoking behavior is undesirable. }\end{array}$ \\
Counseling strategy: patients should be educated about the risks of smoking. \\
Contemplation \\
Although there is awareness that smoking is a problem, there is ambivalence \\
about the perspective of changing; the patient plans to quit within the next 6 \\
months. \\
Counseling strategy: patients are receptive to information about how to change \\
their behavior. \\
There is a readiness to stop smoking, often within the next month, and the \\
patient is determined to do so. \\
Counseling strategy: patients should actively plan a cessation date as a strategy \\
to change the behavior. \\
Smoking cessation: the patient takes the action that leads to the desired \\
change in behavior. \\
Counseling strategy: patients should change their behavior and quit smoking. \\
Maintenance (prevention of relapse)
\end{tabular}

Adapted from Prochaska \& DiClemente. ${ }^{(30}$

cancer, an empathic, positive, direct approach is fundamental: "One of the best things you can do to combat lung cancer is to quit smoking. I can help you." In smokers with tuberculosis, application of the directly observed treatment, short-course (DOTS) strategy in combination with smoking cessation treatment has been shown to improve quality of life. For those patients, it is recommended that a brief intervention be provided at the time of diagnosis and that monthly behavioral support be maintained throughout the duration of the tuberculosis treatment. ${ }^{(32)}$

\section{PHARMACOLOGICAL APPROACH}

In patients with COPD, pharmacological intervention combined with intensive behavioral counseling has been shown to be effective, one meta-analysis demonstrating a high quality of evidence in pooled results, with a relative risk (RR) of 2.53 (95\% CI: 1.83-3.50). ${ }^{(33)}$ Comparing placebo with the use of monotherapy, that same meta-analysis showed that the chance of smoking cessation doubled when bupropion was used $(\mathrm{RR}=2.03 ; 95 \% \mathrm{CI}: 1.26-3.28)$, more than doubled when nicotine replacement therapy (NRT) was used $(\mathrm{RR}=2.60 ; 95 \% \mathrm{CI}: 1.29-5.24)$, and was three times higher when varenicline was used $(R R=3.34 ; 95 \%$ CI: 1.88-5.92). ${ }^{(33)}$

Nortriptyline, a second-line medication, shows no superiority over placebo in terms of achieving smoking cessation in patients with COPD. ${ }^{(34)}$ Among smokers with asthma, the rate of cessation is low, although there have been few studies of the issue. Possible reasons for that include a lack of motivation to quit smoking, as well as other factors, such as depression, low socioeconomic status, and a low level of education. (35) A randomized clinical trial (RCT) involving patients with asthma showed no difference between the use of varenicline and that of placebo in terms of the smoking cessation rate $(\mathrm{RR}=1.25 ; 95 \% \mathrm{CI}: 0.38-4.14)$. $^{(36)}$

With the use of NRT, bupropion, or varenicline, as with any other medication, adverse events may occur. Therefore, all patients using medications for smoking cessation should be monitored. Charts 4 and 5 present the first-line medications for smoking cessation and their main characteristics.

\section{Extended and combined treatment}

There are still few data in the literature to support the long-term use of varenicline. An open observational 
Chart 4. Mechanism of action, absorption, metabolism, presentation, and recommended dosage of first-line smoking cessation drugs.

\begin{tabular}{|c|c|c|}
\hline Medication & & Characteristic \\
\hline \multirow{7}{*}{$\begin{array}{l}\text { Nicotine } \\
\text { replacement } \\
\text { therapy }\end{array}$} & Mechanism of action & $\begin{array}{l}\text { Acts on the nicotinic receptors in the nucleus accumbens, in the } \\
\text { ventral tegmental area of the central nervous system }\end{array}$ \\
\hline & Absorption & $\begin{array}{l}\text { Slow: transdermal patch ( } 75 \% \text { of the dose is absorbed over } 24 \mathrm{~h} \text { ), peak } \\
\text { plasma concentration in } 40 \mathrm{~min} \text {, serum levels stable after } 8-10 \mathrm{~h} \\
\text { Rapid: gum and lozenges ( } 50 \% \text { of the dose is absorbed), peak plasma } \\
\text { concentration in } 20 \text { min }\end{array}$ \\
\hline & Metabolism & $\begin{array}{l}\text { Nicotine is metabolized into cotinine in the liver; minimal renal } \\
\text { elimination in an unaltered form. Only } 5 \% \text { binds to plasma proteins. }\end{array}$ \\
\hline & Formulations & Patch $^{\mathrm{a}}: 21,14$, and $7 \mathrm{mg}$, boxes of 7 \\
\hline & & Guma: 2 and $4 \mathrm{mg}$, boxes of 30 \\
\hline & & Lozenges ${ }^{\mathrm{a}}: 2$ and $4 \mathrm{mg}$, blister packs of 4 or boxes of 36 \\
\hline & Standard dosing schedule & $\begin{array}{l}\text { Patch: For moderate-to-high dependence }(15-20 \text { cigarettes/day): } 21 \\
\mathrm{mg} / \text { day for } 4 \text { weeks, followed by } 14 \mathrm{mg} / \text { day for } 4 \text { weeks and } 7 \mathrm{mg} / \text { day } \\
\text { for } 2-4 \text { weeks } \\
\text { Gum and lozenges: } 2 \mathrm{mg} \text { every } 1-2 \mathrm{~h} \text { for } 4 \text { weeks, followed by } 2 \mathrm{mg} \\
\text { every } 2-4 \mathrm{~h} \text { for } 4 \text { weeks and } 2 \mathrm{mg} \text { every } 4-8 \mathrm{~h} \text { for } 2-4 \text { weeks. Maximum: } \\
20 \text { per day. Dose can be increased to } 4 \mathrm{mg} \text { in the first } 4 \text { weeks in } \\
\text { subjects with high-to-very high dependence }\end{array}$ \\
\hline \multirow[t]{5}{*}{ Bupropion } & Mechanism of action & Inhibition of reuptake of dopamine, norepinephrine, and serotonin \\
\hline & Absorption & $\begin{array}{l}\text { Rapid by the digestive system, reaching peak plasma concentration in } \\
3 \mathrm{~h} \text {, remaining high in patients with renal failure }\end{array}$ \\
\hline & Metabolism & $\begin{array}{l}\text { Half-life of } 21 \mathrm{~h} \text {; metabolized in the liver, mainly by isoenzyme } \\
\text { CYP2B6, which can be affected by several drugs; slow release by the } \\
\text { kidneys ( } 87 \% \text { ); many drug interactions (see Table } 5 \text { ) }\end{array}$ \\
\hline & Formulations & Bupropion hydrochloride tablets, $150 \mathrm{mg}$; boxes of 30 or 60 \\
\hline & Standard dosing schedule & $\begin{array}{l}1 \text { tablet }(150 \mathrm{mg}) \text { in the morning, after breakfast, for the first } 3 \text { days, } \\
\text { followed by } 1 \text { tablet }(150 \mathrm{mg}) \text { in the morning and in the afternoon for } \\
12 \text { weeks }\end{array}$ \\
\hline \multirow[t]{5}{*}{ Varenicline } & Mechanism of action & $\begin{array}{l}\text { Partial agonist of a } 4 B 2 \text { nicotinic receptors (competes with nicotine } \\
\text { for the receptors and releases dopamine) and dopamine reuptake } \\
\text { inhibitor }\end{array}$ \\
\hline & Absorption & $\begin{array}{l}\text { Almost total absorption after oral administration and with high } \\
\text { systemic availability; peak at } 3 \mathrm{~h} \text { and steady state at } 4 \text { days }\end{array}$ \\
\hline & Metabolism & Minimal; renal elimination $(92 \%)$, excreted in an unaltered form \\
\hline & Formulations & $\begin{array}{l}\text { Varenicline tartrate tablets, } 0.5 \mathrm{mg} \text { and } 1 \mathrm{mg} \text {, boxes containing } 11 \\
0.5-\mathrm{mg} \text { tablets }+1541-\mathrm{mg} \text { tablets }\end{array}$ \\
\hline & Standard dosing schedule & $\begin{array}{l}\text { 1st week: } 1 \text { tablet }(0.5 \mathrm{mg}) \text { per day for } 3 \text { days, followed by } 1 \text { tablet } \\
(0.5 \mathrm{mg}) \text { twice daily for } 4 \text { days } \\
\text { 2nd to } 12 \text { th week: } 1 \text { tablet }(1 \mathrm{mg}) \text { twice daily }\end{array}$ \\
\hline
\end{tabular}

Based on Reichert et al. ${ }^{(12)}$; Fiore et al. ${ }^{(13)}$; Jiménez-Ruiz et al. ${ }^{(22)}$; van Eerd et al. ${ }^{(33)}$; Cahill et al. ${ }^{(36)}$; the European Network for Smoking and Tobacco Prevention ${ }^{(37)}$; Brazilian National Ministry of Health ${ }^{(38)}$; and the (U.S.) National Comprehensive Cancer Network. ${ }^{(39)}$ aFormulations available in Brazil.

study involving patients with severe to very severe COPD who used varenicline for 24 weeks showed that the smoking abstinence rate, as assessed by an intention-to-treat analysis, was $17.7 \% .^{(40)}$ However, when studies involving smokers in general were evaluated, pooled data from four RCTs, involving a collective total of 2,170 individuals, indicated that long-term treatment with varenicline was effective $(\mathrm{RR}=3.64 ; 95 \% \mathrm{CI}: 2.1-1-4.72)$. $^{(32)}$

To our knowledge, there have been no RCTs examining the use of reduced doses of varenicline in patients with respiratory diseases. There have been only four RCTs, involving a collective total of 1,266 subjects, showing that varenicline is effective even at doses lower than those recommended for the general smoking population $(\mathrm{RR}=2.08 ; 95 \% \mathrm{CI}: 1.56-2.78) .{ }^{(33)}$ A retrospective study of more than 14,000 patients diagnosed with COPD, with or without cardiovascular or psychiatric comorbidities, showed that, in comparison with the use of NRT, the use of bupropion or varenicline did not increase the risk of cardiovascular or neuropsychiatric events within the first six months of treatment. ${ }^{(41)}$

The combination of two forms of NRT has the same effectiveness as does the use of varenicline (OR = 1.06 ; 95\% CI: $0.75-1.48) .{ }^{(42)}$ A meta-analysis of the pooled data from two RCTs, involving a total of 787 individuals, showed that the combination of varenicline and NRT (the nicotine patch) was more effective than 
Chart 5. Mode of use, precautions, adverse effects, contraindications, efficacy, and combinations of first-line smoking cessation drugs.

\begin{tabular}{|c|c|c|}
\hline Medication & Characteristic & Points to consider \\
\hline \multirow{7}{*}{$\begin{array}{l}\text { Nicotine } \\
\text { replacement } \\
\text { therapy }\end{array}$} & Prescription & Standard prescription \\
\hline & Mode of use & $\begin{array}{l}\text { Initiation: recommended to start on the scheduled cessation date; can be used as } \\
\text { pre-cessation therapy on a case-by-case basis } \\
\text { Patch: apply to the trunk every morning, in hairless areas that are not exposed to } \\
\text { the sun; leave in place for } 24 \text { h; no need to remove for bathing; rotate sites } \\
\text { Gum: chew until tasting the flavor or feeling a tingling sensation; then leave } \\
\text { between the gingiva and the cheek; chew again for } 20-30 \text { min } \\
\text { Lozenge: slowly move it around in the mouth, without sucking, chewing or } \\
\text { swallowing; dissolves in the oral cavity after } 20-30 \text { min }\end{array}$ \\
\hline & Precautions & Avoid citrus drinks and food for $15-30$ min after using nicotine gum or lozenges. \\
\hline & Adverse effects & $\begin{array}{l}\text { Patch: erythema and infiltration of the dermis at the site of application, sialorrhea, } \\
\text { nausea, vomiting, diarrhea, and insomnia } \\
\text { Gum: gingival lesions, sialorrhea, unpleasant taste, dental softening, nausea, } \\
\text { vomiting, dyspepsia, hiccups, and pain in the TMJ } \\
\text { Lozenges: hiccups, sialorrhea, unpleasant taste, and dyspepsia }\end{array}$ \\
\hline & Contraindications & $\begin{array}{l}\text { In the presence of cerebrovascular disease or cardiovascular disease that is severe or } \\
\text { acute (< } 15 \text { days), discuss with the specialist and assess the risk-benefit ratio. } \\
\text { Avoid the use of nicotine gum or lozenges in patients with active peptic ulcer or TMJ } \\
\text { pain. } \\
\text { In patients who are pregnant or breastfeeding, weigh the risk-benefit ratio of a dose } \\
\text { lower than that of smoking and opt for gum or lozenges over the patch. }\end{array}$ \\
\hline & Efficacy & Relative risk of success $=2.60(95 \% \mathrm{Cl}: 1.29-5.24)$ \\
\hline & Combinations & $\begin{array}{l}\text { Patch used in combination with nicotine lozenges or gum } \\
\text { Addition of bupropion or varenicline in cases that are more difficult }\end{array}$ \\
\hline \multirow[t]{7}{*}{ Bupropion } & Prescription & Restricted prescription, in duplicate \\
\hline & Mode of use & $\begin{array}{l}\text { Start } 7 \text { days before the scheduled cessation date. } \\
\text { Take the second tablet in the afternoon, at least } 8 \mathrm{~h} \text { after the first. }\end{array}$ \\
\hline & Precautions & $\begin{array}{l}\text { If possible, avoid taking the } 2 \text { nd dose after } 5: 00 \text { p.m., to reduce the risk of insomnia. } \\
\text { Patients with gastritis should use an antacid and take bupropion with food. } \\
\text { Patients with uncontrolled hypertension should not take bupropion. }\end{array}$ \\
\hline & Adverse effects & $\begin{array}{l}\text { Reduced reflexes (poor performance on tasks that require motor skills), dry mouth, } \\
\text { insomnia, dizziness, headache, agitation, anxiety, tremors }\end{array}$ \\
\hline & $\begin{array}{l}\text { Contraindications } \\
\text { and drug } \\
\text { interactions }\end{array}$ & $\begin{array}{l}\text { Numerous drug interactions } \\
\text { Relative: harmful use of alcohol; and the use of carbamazepine, barbiturates, } \\
\text { phenytoin, antipsychotics, antidepressants, cimetidine, theophylline, systemic } \\
\text { corticosteroids, oral hypoglycemic agents, and insulin } \\
\text { Absolute: epilepsy and seizures (including febrile seizures), recent alcohol } \\
\text { withdrawal, cerebrovascular disease, bulimia, anorexia nervosa, panic attacks, use } \\
\text { of MAO inhibitors in the last } 14 \text { days, < } 16 \text { years of age, pregnancy, and breastfeeding }\end{array}$ \\
\hline & Efficacy & Relative risk of success $=2.03(95 \% \mathrm{Cl}: 1.26-3.28)$ \\
\hline & Combinations & $\begin{array}{l}\text { Addition of nicotine replacement therapy or varenicline in cases that are more } \\
\text { difficult }\end{array}$ \\
\hline \multirow[t]{7}{*}{ Varenicline } & Prescription & Standard prescription \\
\hline & Mode of use & $\begin{array}{l}\text { Start } 7 \text { days before the scheduled cessation date } \\
0.5-\mathrm{mg} \text { tablets only for the } 1 \text { st week, then } 1-\mathrm{mg} \text { tablets twice daily for } 11 \text { weeks }\end{array}$ \\
\hline & Precautions & $\begin{array}{l}\text { The bioavailability is not affected by eating or by the schedule of administration; it } \\
\text { can be taken after meals. }\end{array}$ \\
\hline & Adverse effects & $\begin{array}{l}\text { Most common: nausea (in } 33 \% \text {, rarely requiring discontinuation); and vivid dreaming } \\
\text { Some patients report dizziness, dry mouth, drowsiness, and flatulence. } \\
\text { It can be associated with depressive mood, suicidal ideation, and lack of control } \\
\text { of psychiatric disorders, although such symptoms can also occur due to withdrawal } \\
\text { syndrome. }\end{array}$ \\
\hline & $\begin{array}{l}\text { Contraindications } \\
\text { and drug } \\
\text { interactions }\end{array}$ & $\begin{array}{l}\text { Few drug interactions } \\
\text { Use with caution in smokers with severe psychiatric disorders (psychotic outbreak, } \\
\text { suicidal ideation/attempt, etc.): discuss with the psychiatrist. }\end{array}$ \\
\hline & Efficacy & Relative risk of success $=3.35(95 \% \mathrm{Cl}: 1.89-5.92)$ \\
\hline & Combinations & $\begin{array}{l}\text { Addition of nicotine replacement therapy or bupropion in cases that are more } \\
\text { difficult }\end{array}$ \\
\hline
\end{tabular}

Based on Reichert et al.(12); Fiore et al.(13); Jiménez-Ruiz et al.(22); van Eerd et al.(33); Cahill et al.(36); European Network for Smoking and Tobacco Prevention ${ }^{(37)}$; Brazilian National Ministry of Health ${ }^{(38)}$; and the (U.S.) National Comprehensive Cancer Network. ${ }^{(39)}$ TMJ: temporomandibular joint; and MAO: monoamine oxidase. 
was the use of varenicline alone $(\mathrm{OR}=1.62 ; 95 \% \mathrm{CI}$ : $1.18-2.23){ }^{(43)}$

\section{SMOKING AND RESPIRATORY DISEASES}

\section{Asthma and smoking}

Asthma is a heterogeneous disease, with a variety of phenotypes, that results from complex interactions between environmental and genetic factors. Prenatal and postnatal exposure to environmental tobacco smoke (ETS) is associated with an increased risk of developing asthma-like symptoms in childhood. ${ }^{(44,45)}$

In a systematic review with meta-analysis, ${ }^{(44)}$ prenatal and postnatal exposure to ETS were found to be associated with a $30-70 \%$ increase in the risk of incident wheezing among children $\leq 2$ years of age. In that study, postnatal maternal smoking was shown to have a greater effect on the development of wheezing among such children (OR $=1.70 ; 95 \%$ CI: $1.24-2.35$ ), with a $21-85 \%$ increase in the risk of incident asthma, whereas prenatal maternal smoking was shown to have a greater effect on the development of asthma (OR $=1.85 ; 95 \% \mathrm{CI}: 1.35-2.53$ ).

In another systematic review with meta-analysis, ${ }^{(45)}$ prenatal maternal smoking was found to be associated with an increased risk of wheezing in children $<6$ years of age (OR $=1.36 ; 95 \% \mathrm{CI}: 1.19-1.55)$, as well as with an increased risk of wheezing or asthma in children $\geq 6$ years of age (OR $=1.22 ; 95 \% \mathrm{CI}$ : 1.03-1.44). One study showed that postnatal exposure to ETS was associated with wheezing in children $<6$ years of age $(\mathrm{OR}=1.21 ; 95 \% \mathrm{CI}: 1.13-1.31$ and $\mathrm{OR}$ $=1.30 ; 95 \% \mathrm{CI}: 1.13-1.51$ for maternal and paternal smoking, respectively), although it was often impossible to separate the role of postnatal exposure from that of prenatal exposure. ${ }^{(46)}$

In some patient samples, it has been shown that the likelihood of incident asthma increases after smoking cessation. ${ }^{(47-49)}$ In one such sample, continued smoking during follow-up was also found to increase the risk of incident asthma significantly. ${ }^{(47)}$

To our knowledge, there have as yet been no studies evaluating asthma mortality attributable to smoking or the fraction of asthma attributable to active and passive smoking in Brazil. In 2013 in Brazil, there were more than 120,000 hospitalizations for asthma and 2,047 asthma-related deaths (5 deaths/day). ${ }^{(50)}$ In individuals with asthma, smoking is associated with an accelerated decline in lung function, ${ }^{(51)}$ as well as with a poor response to inhaled and systemic corticosteroids. ${ }^{(52-55)}$ In addition, smokers with asthma have a lower chance of achieving control of the disease, as well as a higher frequency of asthma exacerbations and hospitalizations due to such exacerbations. ${ }^{(56-59)}$

An association between marijuana smoking and the worsening of asthma symptoms has been recognized since the 1970 s. $^{(60-62)}$ Smoking marijuana also exacerbates bronchial asthma and provokes symptoms consistent with asthma. (60-64) Passive exposure to marijuana smoke (inhalation of toxic substances) worsens the symptoms of asthma. ${ }^{(65)}$ Therefore, individuals with asthma or bronchial hyperresponsiveness should avoid active and passive smoking of tobacco or marijuana.

Smoking cessation reduces asthma symptoms and allows better control of the disease. ${ }^{(66,67)}$ There is some evidence to suggest that smokers with asthma are less likely to quit smoking than are those without asthma. ${ }^{(68,69)}$

In every patient with asthma or bronchial hyperresponsiveness, the physician should inquire about the smoking status. In the counseling sessions, physicians should emphasize the following:

- Individuals with asthma or bronchial hyperresponsiveness should avoid active and passive smoking of tobacco and marijuana.

- Nonsmokers should be advised not to start smoking.

- Tobacco smokers and marijuana smokers should be informed of the difficulties and risks of continuing to smoke those products and should receive support for smoking cessation.

The main benefits of smoking cessation in individuals with asthma include improving asthma control, reducing exacerbations, slowing the functional decline, and improving the therapeutic response.

\section{COPD and smoking}

COPD is a multisystem inflammatory disease that results from the interaction between genetic and environmental factors. Although cigarette smoke continues to be the main cause of the disease, there are regions in which the inhalation of smoke from biomass burning, occupational exposure, and air pollution also play relevant roles. ${ }^{(70-74)}$

The smoking history, which is related to the development, progression, and severity of COPD, is typically expressed in pack-years. However, the duration of smoking in years, in addition to being easier to evaluate, might correlate better with the risk of the development and progression of the disease. ${ }^{(75)}$

The prevalence of COPD varies depending on the risk factors, functional criteria, and analytical criteria. . $^{(7,77)}$ The estimated prevalence of COPD worldwide and in Brazil is $12 \%$ and $15.8 \%$, respectively. ${ }^{(70,78)}$ Because age and smoking have a cumulative effect, it is estimated that $50 \%$ of smokers will develop the disease during their lifetime. ${ }^{(79,80)}$

COPD is now the third leading cause of death worldwide. A study conducted in the capital cities of Brazil found that $65 \%$ of the deaths attributable to smoking are in individuals with COPD, ischemic heart disease, lung cancer, or cerebrovascular disease. ${ }^{(81)}$ In another study, comparing mortality rates in Brazil between 1990 and 2015,(82) there was a 31\% reduction in the rate of mortality from COPD (from 64.5 to $44.5 / 100,000$ inhabitants), compared with a reduction of only $2.1 \%$ in the rate of mortality from lung cancer. In that same period, there was a $36.1 \%$ 
reduction in the number of years of life lost due to death or disability.

Patients with COPD tend to conceal the fact that they still smoke from their physicians, even when their cotinine or exhaled carbon monoxide level belies their self-reported smoking status. ${ }^{(83)}$ Smokers with COPD have a greater smoking intensity and a higher level of nicotine dependence, requiring more guidance on the risks of and need to quit smoking, than do smokers without COPD. $(20,84)$

The level of motivation to quit smoking differs little between patients with and without COPD. However, self-efficacy is lower in smokers with COPD, partly because of the high prevalence of anxiety and depression among such individuals. ${ }^{(20,70,84)}$ In a sample of smokers with COPD in Denmark, the factors related to the lower chance of smoking cessation were being $<65$ years of age; having mild airflow obstruction; being classified as being in Global Initiative for Chronic Obstructive Lung Disease risk group A; scoring low on the Medical Research Council scale; and having a low socioeconomic status. ${ }^{\left({ }^{85}\right)}$ In that sample, depression was not found to worsen the smoking cessation rate, as was shown in another study. ${ }^{(85)}$

Smoking cessation is the only intervention that alters the natural history of COPD. $(20,70,71)$ Smokers with COPD are more likely to be questioned about their smoking, receiving more guidance and treatment, than are those without COPD. However, when they are not encouraged to quit smoking or referred to smoking cessation programs, they maintain their smoking habits almost unchanged for several years. ${ }^{\left({ }^{87}\right)}$ Chart 6 summarizes the treatment recommendations and benefits of smoking cessation in patients with COPD.

\section{Lung cancer and smoking}

Cigarette smoke contains more than 7,000 compounds. ${ }^{(93)}$ According to the International Agency for Research on
Cancer, more than 60 of those compounds have been shown to be carcinogenic in laboratory animals, and there is sufficient evidence that 12 of those are carcinogenic to humans. ${ }^{(94,95)}$ There is a strong correlation between lifetime smoking and genetic changes (DNA methylation and microRNA changes) leading to inactivation of tumor suppressor mechanisms. ${ }^{(71,96-98)}$ Active and passive smoking are responsible for more than $90 \%$ of lung cancer cases, with a direct correlation between packyears of smoking and an increased risk of cancer. ${ }^{(71,97)}$

Studies conducted in Brazil have shown that the incidence and mortality rates of smoking-related cancer, particularly in the lungs, oral cavity, and larynx, are high in the country. ${ }^{(99,100)}$ A study evaluating the proportion of cancer cases attributed to modifiable risk factors in Brazil estimated that, by 2020 , the proportion of cases of lung cancer attributable to smoking will be $83.28 \%$ in men and $64.80 \%$ in women. ${ }^{(100,101)}$

In a systematic review of studies involving patients with early-stage lung cancer who continued to smoke, ${ }^{(102)}$ continued smoking among those with non-small cell lung cancer was found to increase the risk of relapse (RR = 1.86 ; $95 \% \mathrm{CI}: 1.01-3.41)$ and all-cause mortality (RR $=2.94 ; 95 \% \mathrm{CI}: 1.15-7.54)$. In patients with limited small cell lung cancer who continued to smoke, there were also increases in the risk of relapse $(R R=1.26$; 95\% CI: $1.06-1.50)$, a second primary tumor ( $R R=$ 4.31; 95\% CI: 1.09-16.98), and all-cause mortality $(\mathrm{RR}=1.86 ; 95 \% \mathrm{CI}: 1.33-2.59)$. Among the patients with non-small cell lung cancer $\geq 65$ years of age, the authors found that the survival rate was $33 \%$ for those who continued to smoke and $70 \%$ for those who had quit smoking. The 5 -year survival rate in the small cell tumor group was $29 \%$ among those who continued to smoke and $63 \%$ among those who had quit.

Smokers with cancer live with the pressure to quit smoking exerted by their physician and their family, as well as internal pressure to do so, blaming themselves

Chart 6. Recommendations for the approach to smoking cessation and benefits of cessation in patients with COPD.

Description

Consultation

Start of treatment

Treatment strategy

Benefits of smoking cessation
Recommendations

All patients with COPD should be asked if they smoke and, if so, should be encouraged to stop smoking and referred to a smoking cessation program.

Smoking cessation treatment alters the natural course of COPD.

Begin smoking cessation treatment as part of COPD treatment.

Combining behavioral counseling with first-line drugs (nicotine replacement therapy, bupropion, and varenicline) is the most effective approach.

Patients who have more difficulty in quitting smoking can benefit from the use of more than one drug or high-dose nicotine patches.

In patients with COPD, the benefits vary depending on age, severity, and comorbidities.

Main benefits:

Slows the progressive decline in FEV

Reduces exacerbation and hospitalization rates

Minimizes respiratory symptoms and improves quality of life

Reduces the limitations in activities of daily living

Improves the ability to perform activities of daily living

Improves the control of comorbidities

Improves the response to bronchodilators and inhaled corticosteroids

Based on Jiménez-Ruiz et al.(20); Jiménez-Ruiz et al.(22) van Eerd et al.(33); the Global strategy for the diagnosis, management, and prevention of chronic obstructive pulmonary disease ${ }^{(70)}$; the U.S. Department of Health and Human Services ${ }^{(71)}$; Bai et al. ${ }^{(88)}$; Tonnesen et al. ${ }^{\left({ }^{89}\right)}$; Godtfredsen et al. ${ }^{(90)}$; Anthonisen et al. ${ }^{(91)}$; and Anthonisen et al. ${ }^{(92)}$ 
for the development of the disease, although most such smokers want to quit. The threats of physical pain, psychological suffering, and death, as well as future challenges, hamper the decision-making process of some patients and motivate others to quit smoking. The distorted thought of it being too late to quit smoking also hampers that process. ${ }^{(103)}$

A patient can oscillate between moments of high and low self-efficacy to quit smoking. That requires the physician to be sensitivity to the difference between those two states and to promote an individualized approach focusing on the benefits of smoking cessation, which will promote better treatment outcomes. ${ }^{(103-105)}$ Approximately $50 \%$ of all smokers diagnosed with cancer continue to smoke. ${ }^{(106)}$ Smokers with lung cancer are more motivated to quit smoking than are those in the general population, although they can require care that is more intensive and comprehensive. ${ }^{(103)}$

Smoking is an independent prognostic factor for lung cancer, the only one that is under the direct control of the patient. Although smoking abstinence rates are high after diagnosis, relapse rates are also high. Treatment and prevention of relapse are imperative since the first visit. $^{(103)}$ Chart 7 summarizes the key recommendations in the approach to smoking cessation treatment in patients with lung cancer, as well as emphasizing the benefits of cessation during cancer treatment.

\section{Tuberculosis and smoking}

In 2016, there were 10.4 million new cases of tuberculosis and 1.7 million tuberculosis-related deaths, more than $95 \%$ of which occurred in low- and middleincome countries. ${ }^{(110)}$ Brazil is among the 22 countries that account for $80 \%$ of all cases of tuberculosis worldwide. According to the Brazilian National Ministry of Health, there were 4,374 tuberculosis-related deaths in Brazil in 2014. ${ }^{(111)}$ Tuberculosis and smoking are both more common in low- and middle-income countries. According to the World Health Organization, more than $20 \%$ of all new cases of tuberculosis can be attributed to smoking. ${ }^{(112)}$

Smoking was identified as a risk factor for tuberculosis a century ago. ${ }^{(113)}$ In the last decade, several studies have demonstrated that, even after adjustment for other risk factors, there is a significant association between exposure to tobacco smoke and tuberculosis. ${ }^{(114)}$ There is evidence that active and passive smoking are associated with active tuberculosis, as well as with the treatment response, relapse, and tuberculosis-related mortality. ${ }^{(71,112,114-116)}$ These effects appear to be independent of other risk factors for tuberculosis, such as alcoholism and socioeconomic conditions. ${ }^{(71,112,114)}$

Tobacco smoke impairs the pulmonary defense mechanisms by effecting structural changes, cellular changes, and an altered immune response. Smoking

Chart 7. Recommendations for the approach to smoking cessation and benefits of cessation in patients with lung cancer.

Description

Consultation

Chart

Start of treatment

Treatment strategy

Nicotine

replacement therapy

Bupropion

Varenicline

Benefits of smoking

cessation

\section{Recommendation}

All patients should be asked if they smoke.

Insert a category for smoking status in the patient chart, as one more vital sign. ${ }^{a}$

Initiating treatment in the preoperative period increases cessation rates.

Smoking cessation treatment should be integrated into the cancer treatment strategy.

Counseling alone is indicated only when pharmacotherapy is contraindicated or refused by the patient.

Pharmacotherapy is usually similar to that used in the general population.

First-line pharmacotherapy, in combination with counseling, is cost-effective and should be offered to all patients who smoke, including those in follow-up treatment.

Patients undergoing chemotherapy or radiotherapy should receive counseling and pharmacotherapy.

Pre-cessation nicotine replacement therapy and counseling provide the best results.

Consider using combined therapy, extended therapy, and higher doses of nicotine replacement therapy.

Patch: its use is inadvisable in patients with graft-versus-host disease.

Gum/lozenges: can accentuate mucositis after chemotherapy.

Its use is indicated in patients with depressive symptoms.

It can inactivate tamoxifen and is contraindicated in patients with metastases in the central nervous system.

It can exacerbate the nausea caused by chemotherapy.

Greater chances of survival; a lower risk of relapse; a lower incidence of a second smoking-

related primary tumor

Better treatment efficacy and response; improved quality of life and pain control; and higher self-esteem

Lower risk of surgical complications (pulmonary embolism, suture dehiscence, and infections), as well as of complications of radiotherapy and chemotherapy Lower risk of developing or worsening of other smoking-related diseases

Based on Álvares et al. (98); Cinciripini et al.(105); Gritz et al. 2014(106); the American Society of Clinical Oncology(107); Shields et al. ${ }^{(108)}$; and Koshiaris et al.(109) ${ }^{2}$ Increases the rate at which physicians and other health professionals intervene for smoking cessation. 
disrupts the integrity of the airway epithelium, alters mucociliary clearance, and reduces the phagocytic capacity of alveolar macrophages, which increases the likelihood that Mycobacterium tuberculosis will reach the alveoli, where tuberculosis infection begins. ${ }^{(71,117-121)}$ Some studies suggest that increased susceptibility to pulmonary tuberculosis is due to reductions in circulating immunoglobulin levels and in the CD4/ CD8 ratio, both of which are caused by exposure to tobacco smoke. ${ }^{(71,122-126)}$

Passive smoking increases both the risk of tuberculosis infection and the occurrence of active tuberculosis, especially in children. That risk is increased up to ninefold in individuals under 15 years of age, even those who have had no contact with pulmonary tuberculosis in the home. There is a strong dose-response relationship between the risk of tuberculosis and the volume of tobacco smoke (number of cigarettes) to which children are exposed per day. ${ }^{(127,128)}$ Nonsmokers exposed to tobacco smoke in closed spaces are also at an increased risk of developing pulmonary tuberculosis. ${ }^{(129)}$ Among individuals with tuberculosis, those who smoke are at an increased risk of the most severe clinical manifestations, mortality, a delay in achieving sputum negativity, treatment failure, tuberculosis relapse, resistance to antituberculosis drugs, cavitary lesions, greater sputum positivity, and sequelae that are more extensive. $(71,114,115,124,130-133)$

Among individuals with active tuberculosis who have no previous history of tuberculosis, the risk of death from tuberculosis is nine times higher in smokers than in those who have never smoked. ${ }^{(134)}$

Smoking control is an important strategy to reduce the number of individuals infected with $M$. tuberculosis and that of those who will develop the disease. Therefore, it is essential to advise smokers with tuberculosis to quit smoking and to support them in that endeavor. When smokers with tuberculosis quit smoking, they reduce their risk of death from tuberculosis by approximately $65 \%$ in comparison with those who continue to smoke. ${ }^{(134)}$ The World Health Organization recommends that tuberculosis control programs work in an integrated way with anti-smoking programs, so that smoking cessation treatment is offered to every patient with tuberculosis. ${ }^{(112,114,115)}$

\section{Environmental respiratory diseases and smoking}

Smoking, environmental air pollution, and indoor air pollution are risk factors for mortality, respectively accounting for 7.13, 4.3, and 2.6 million deaths/year, ranking second, sixth, and eighth, worldwide. ${ }^{(135)}$ In Brazil, environmental air pollution ranks eleventh among mortality risk factors.

Diseases related to exposure to particulate matter, gases, and carcinogens occur due to oxidative stress, pulmonary inflammation, systemic inflammation, and DNA damage. The main diseases related to exposure to environmental pollutants are ischemic cardiovascular diseases, neoplasms, COPD, and respiratory infections. ${ }^{(137)}$

According to the World Health Organization estimates for 2016, environmental air pollution and indoor air pollution in Brazil were respectively responsible for 51,800 and 14,100 deaths, with standardized mortality rates of 24/100,000 population and 7/100,000 population. ${ }^{(138)}$ One group of authors, estimating the level of inhaled particulate matter at $12 \mathrm{mg} /$ cigarette and the exposure to air pollution at $13-30 \mu \mathrm{m}^{3}$ of air/ day, concluded that those exposures increase the risk for lung cancer, cardiovascular disease, and lung disease in general. ${ }^{(139)}$

In one study, lung function values were found to be lower in women (smokers and nonsmokers) who lived in environments with high levels of pollution than in those who lived in environments with lower levels of pollution. ${ }^{(140)}$ The authors also found that exposure of smokers to ETS increases their risk of lung cancer, showing an additive effect.

No differences have been identified among the various profiles of smokers in terms of the risk of diseases related to air pollution. Although the isolated impact of smoking cessation in individuals exposed to pollution is not yet known, the ban on smoking indoors has had a significant impact on reducing morbidity and mortality. A meta-analysis of 44 studies showed significant reductions in the rates of hospitalization and death from respiratory diseases. ${ }^{(141)}$ This suggests that people living in the same city, without changes in pollution levels, could benefit from reduced ETS exposure. The same holds true for the impact of smoking cessation on the reduction in the incidence of respiratory diseases observed in cohort studies. ${ }^{(142)}$

\section{Occupational respiratory diseases and smoking}

The combination of exposure to tobacco smoke and occupational exposure to pollutants is associated with deleterious and sometimes synergistic effects, potentiating injuries to the airways and the pulmonary interstitium. Inhibition of mucociliary clearance and other changes in the airways result in increased retention of inhaled particles, as well as facilitating damage from the inhalation of gases, mists, or chemical vapors. The pro-inflammatory nature and DNA toxicity of both exposures can increase the risk of becoming ill. ${ }^{(97,143,144)}$

Occupational exposure to pollutants is a major risk factor for morbidity and mortality worldwide, the various occupational risks collectively estimated to be responsible for 1.53 million deaths/year and 75.93 million years of life lost to death or disability. ${ }^{(145)}$ According to data on the global burden of diseases in 2016, exposure to ETS in the workplace alone was associated with 433,200 deaths, having the greatest impact on mortality from ischemic cardiovascular diseases (252,000 deaths), followed by mortality from COPD (52,000 deaths) and mortality from lung cancer (44,400 deaths). ${ }^{(146)}$ 
The prevalence of smoking among workers varies depending on the type of company and its activity, being lower among workers in the health and education sectors, whereas it is higher among those in the industrial, janitorial, mining, and construction sectors. ${ }^{(147)}$ In the latter groups of workers, the prevalence is higher than in the general population, in several countries: $53.2 \%$ vs. $40.2 \%$ in China ${ }^{(148)}$. $66.3 \%$ vs. $43.0 \%$ in Turkey ${ }^{(149)}$; and $49.8 \%$ vs. $15.1 \%$ in Brazil. (150) Those high rates reveal the impact of smoking among the less educated and those with lower incomes, who make up the workforce that engages in insalubrious activities or is exposed to greater occupational risks.

Smoking cessation reduces the risk of morbidity and mortality, an earlier age at cessation translating to a greater benefit. ${ }^{(151)}$ It is recommended that the occupational health departments of companies develop policies to encourage smokers and their families to quit smoking and to support them in that endeavor, from the hire date onward. Providing treatment to smokers should be incorporated into the routine at primary health care clinics and in companies. ${ }^{(152)}$

Conducting research with brief questionnaires to monitor the health/illness relationship not only helps identify the need for interventions in the workplace but also can create important motivational moments, thus increasing the chance of success in smoking cessation. Chief among the various motivating factors for quitting smoking presented by groups of workers who are more exposed and more socially vulnerable are the presence of respiratory symptoms and established respiratory disease. ${ }^{(149)}$

\section{Interstitial respiratory diseases and smoking}

In recent years, concern about the harmful effects of smoking has begun to focus on the development of interstitial lung diseases (ILDs). Among such diseases, three are considered to be etiologically related to smoking ${ }^{(153)}$ : ILD accompanied by respiratory bronchiolitis; desquamative interstitial pneumonia; and pulmonary Langerhans cell histiocytosis.

Certain interstitial diseases are more likely to develop in smokers, such as idiopathic pulmonary fibrosis and rheumatoid arthritis-related ILD. ${ }^{(153)}$ Some individuals also develop a combination of pulmonary fibrosis and emphysema. That combination is considered a distinct phenotype of idiopathic pulmonary fibrosis. ${ }^{(154)}$

It is important to identify the role of smoking in ILD, because understanding the pathogenic pathways could allow the development of new medications. From a clinical point of view, the recognition of a smokingrelated phenotype would facilitate early diagnosis and treatment. ${ }^{(155)}$

One group of authors analyzed four prospective cohort studies, involving a collective total of 11,691 participants, and assessed mortality in subjects with interstitial lung abnormalities. ${ }^{(156)}$ The abnormalities were associated with greater smoking intensity in two of those studies and with higher mortality rates in all four

Although smoking-related ILDs are less well recognized, there is a well-defined causal correlation, based on epidemiological data, between smoking and the development of an ILD. Smoking cessation is the primary therapy for the control of such ILDs, and the approach requires perfect integration of clinical, functional, radiological, and histopathological data.

\section{Infectious respiratory diseases and smoking}

Deposition of the toxic constituents of tobacco smoke in the airways affects the pulmonary defense mechanisms in multiple ways ${ }^{(157)}$ : by impairing mucociliary transport; by increasing bacterial adherence to the respiratory epithelium; and by increasing alveolar and epithelial vascular permeability. In addition, continued exposure to tobacco smoke is associated with significant changes in the nasopharyngeal microflora, which favors colonization by opportunistic pathogens. ${ }^{(158)}$

One experimental study in mice demonstrated that chronic exposure to ETS increased levels of inflammatory cytokines and TNF- $a$ in the lungs, as well as impairing adaptive immunity, after chronic infection or intranasal immunization with the recombinant P6 protein of Haemophilus influenzae. ${ }^{(159)}$ The authors concluded that there is unequivocal evidence that exposure to ETS has long-term effects that are detrimental to the lung microenvironment (promoting inflammation), as well as impairing immunity to infection and the response to vaccination.

In one systematic review, ${ }^{(160)}$ the risk of contracting bacterial pneumonia was shown to be higher in smokers than in former smokers (hazard ratio $=1.37 ; 95 \% \mathrm{CI}$ : $1.06-1.78$ ) and nonsmokers (hazard ratio $=1.73 ; 95 \%$ CI: 1.44-2.06). Pneumonia and influenza increase the risk of morbidity and mortality. When the individual is a smoker, the social, medical, and pension costs are further increased. A 2017 study showed that pneumonia is the third leading smoking-related illness in Brazil. ${ }^{(2)}$ Chart 8 summarizes the scientific evidence regarding the exposure and risks of smokers.

\section{Smoking among inpatients with respiratory diseases}

The reported prevalence of smoking among hospitalized patients in Brazil ranges from $15 \%$ to $22 \%$. ${ }^{(167,168)}$ In one study, ${ }^{(169)}$ the authors found a $25 \%$ prevalence of smoking among inpatients at a smoke-free hospital, and $55 \%$ of the patients who were smokers experienced withdrawal symptoms during their hospital stay. In a systematic review, ${ }^{(170)}$ the prevalence of smoking among inpatients was found to range from $15 \%$ to $27 \%$.

Hospitalization creates a window of opportunity to initiate anti-smoking measures with a high chance of success, especially if there is follow-up after hospital discharge. ${ }^{(12,169)}$ Addressing the issue of smoking among inpatients who are smokers should be part of 
Chart 8. Recommendations for the approach to smoking cessation, benefits of cessation, and risks in patients with infectious respiratory diseases.

\begin{tabular}{|c|c|}
\hline Description & Recommendation \\
\hline Consultation & $\begin{array}{l}\text { Patients should be encouraged to stop smoking and should be referred to a smoking } \\
\text { cessation program. }\end{array}$ \\
\hline Risks of active smoking & $\begin{array}{l}\text { High risk of varicella-zoster virus pneumonitis } \\
\text { Two times higher risk of influenza, with worse clinical evolution } \\
\text { Four times higher risk of pneumonia in patients with COPD } \\
\text { Higher risk of pneumonia in HIV-infected patients } \\
\text { Two times higher risk of community-acquired pneumonia } \\
\text { Smoking is an aggravating factor for other respiratory infections }\end{array}$ \\
\hline Risks of passive smoking & $\begin{array}{l}\text { Exposure to environmental tobacco smoke is associated with Mycobacterium } \\
\text { tuberculosis infection and active pulmonary tuberculosis }\end{array}$ \\
\hline Treatment strategy & Combine behavioral counseling with first-line medications \\
\hline Benefits of smoking cessation & $\begin{array}{l}\text { Reduces the risk of respiratory infections in active and passive smokers, especially } \\
\text { children }\end{array}$ \\
\hline
\end{tabular}

the hospital routine. Although such patients are often highly motivated and amenable, only a minority receive smoking cessation treatment and most of those relapse after hospital discharge. ${ }^{(12,169)}$

The recommended course of action in the approach to inpatients who are smokers is to offer counseling during hospitalization and follow-up for at least four weeks after discharge, either in person or by telephone. In a meta-analysis of 50 studies, ${ }^{(171)}$ it was concluded that intensive approaches with follow-up after discharge were more effective, because relapse typically occurs during the first month after discharge. Identifying the level of craving and other factors that indicate a greater chance of failure, such as dependence on alcohol or other drugs, allows the treatment of inpatients at higher risk of relapse to be individualized.

In a study evaluating the efficacy of a smoking cessation program for patients hospitalized for respiratory disease or heart disease, $31 \%$ of the patients with respiratory diseases were reported to be abstinent at six months after discharge. ${ }^{(172)}$ Patients receiving individual counseling and medication for smoking cessation during hospitalization and after discharge showed greater adherence to the treatment, even after hospital discharge. ${ }^{(173)}$

Hospital admission should be transformed into an opportunity for smoking cessation. Smokers hospitalized for respiratory diseases should be advised of the benefits of quitting smoking, as well as being assessed in terms of their level of motivation and level of nicotine dependence in order to receive specific treatment, which is similar to that recommended for patients with other conditions. Smoking cessation programs involving teams trained in dealing with smokers have good cost-effectiveness ratios. ${ }^{(174)}$ Follow-up for at least six months after discharge improves outcomes and increases the chance of successful abstinence. ${ }^{(170,175,176)}$ Intensive intervention combined with pharmacological treatment for smoking cessation in patients with respiratory disease, started during hospitalization, is effective, with a high level of evidence. ${ }^{(22)}$

\section{FINAL CONSIDERATIONS}

All patients with respiratory diseases should be asked if they smoke. If so, they should be encouraged to quit smoking and referred for smoking cessation treatment, regardless of their age and disease stage. Smoking cessation treatment, based on cognitive-behavioral therapy and pharmacotherapy, is the first measure to be taken in the treatment of lung diseases and has major benefits: fewer exacerbations and hospitalizations; a reduction in respiratory symptoms; an improvement in quality of life; fewer limitations in activities of daily living; better control of comorbidities; improved response to bronchodilators and inhaled corticosteroids; greater chances of survival; a lower risk of relapse; a lower incidence of a second smoking-related primary tumor; better pain control; improved self-esteem; and a lower risk of complications from surgery, radiotherapy, and chemotherapy.

\section{REFERENCES}

1. World Health Organization [homepage on the Internet]. WHO, Geneva; Fact Sheet [updated 2018 Mar 9, cited 2018 Aug 26] Tobacco [about 8 screens]. Available from: http://www.who.int/en/ news-room/fact-sheets/detail/tobacco

2. Instituto de Efectividad Clínica y Sanitaria; Instituto Nacional do Câncer; Fundação Oswaldo Cruz [homepage on the Internet], ACT Promoção da Saúde [updated 2017 May 31, cited 2018 Aug 26] Carga de doença atribuível ao uso do tabaco no Brasil e potencia impacto do aumento de preços por meio de impostos [about 2 screens]. Available from http://actbr.org.br/post/carga-de-doencaatribuivel-ao-uso-do-tabaco-no-brasil-e-potencial-impacto-do- aumento-de-precos-por-meio-de-impostos/16952/

3. Brasil. Ministério da Saúde [homepage on the Internet]. Brasília: o Ministério; c2018 [cited 2018 Aug 26]. Vigitel Brasil 2017-Vigilância de Fatores de Risco e Proteção para Doenças Crônicas por Inquérito. [Adobe Acrobat document, 132 p.]. Available from: http://bvsms. saude.gov.br/bvs/publicacoes/vigitel_brasil_2017_vigilancia_fatores_ riscos.pdf

4. Brasil. Instituto Brasileiro de Geografia e Estatística [homepage on the Internet]. São Paulo: IBGE; c2018 [cited 2018 Aug 26]. Projeção da População do Brasil e das Unidades de Federação. Available from: https://www.ibge.gov.br/apps/populacao/projecao/ 
5. Instituto Nacional do Câncer José Alencar Gomes da Silva (INCA) [homepage on the Internet]. Rio de Janeiro: INCA; c2012 [cited 2018 Aug 26]. Convenção-quadro para o controle do tabaco: texto oficial, 2011. [Adobe Acrobat document, 58p]. Available from http://www. saude.pr.gov.br/arquivos/File/convencao_quadro_texto_oficial.pdf

6. World Health Organization. WHO Report on the Global Tobacco Epidemic, 2008: The MPOWER. Geneva: World Health Organization 2008.

7. Levy D, de Almeida LM, Szklo A. The Brazil SimSmoke policy simulation model: the effect of strong tobacco control policies on smoking prevalence and smoking-attributable deaths in a middle income nation. PLoS Med. 2012;9(11):e1001336. https://doi. org/10.1371/journal.pmed.1001336

8. Instituto Nacional do Câncer José Alencar Gomes da Silva (INCA [homepage on the Internet]. Rio de Janeiro: INCA; c2018 [cited 2018 Aug 26]. Programa Nacional de Controle do Tabagismo labout 5 screens]. Available from: http://www2.inca.gov.br/wps/wcm/ connect/acoes_programas/site/home/nobrasil/programa-nacionalcontrole-tabagismo

9. Araujo AJ. Tratamento do tabagismo pode impactar a DPOC. Pulmao RJ - Atualizações Temáticas. 2009;1(1):20-33. http://www.sopterj. com.br/wp-content/themes/_sopterj_redesign_2017/_revista/ atualizacao_tematica/03.pdf

10. Corrêa da Silva LC, Araújo AJ, Queiroz ÂM, Sales MD, Castellano MV; Comissão de Tabagismo da SBPT. Smoking control: challenges and achievements. J Bras Pneumol. 2016;42(4):290-298. http:// www.jornaldepneumologia.com.br/detalhe_artigo.asp?id=2566

11. Schmidt MI, Duncan BB, Azevedo e Silva G, Menezes AM, Monteiro CA, Barreto SM, et al. Chronic non-communicable diseases in Brazil: burden and current challenges. Lancet. 2011;377(9781):1949-61. [cited 2018 Aug 26]. Available from: https://www.thelancet.com/ pdfs/journals/lancet/PIIS0140-6736(11)60135-9.pdf

12. Reichert J, Araujo AJ, Gonçalves CM, Godoy I, Chatkin JM, Sales MP, et al. Smoking cessation guidelines-2008. J Bras Pneumol. 2008;34(10):845-80. http://jornaldepneumologia.com.br/detalhe_ artigo.asp?id $=817$

13. Fiore MC, Jaén CR, Baker TB, Bailey WC, Benowitz NL, Curry SJ, et al. Treating Tobacco Use and Dependence: 2008 Update--Clinical practice guideline. Rockville: US Department of Health and Human Services; 2008. https://www.ncbi.nlm.nih.gov/books/NBK63952/

14. Tønnesen P. Smoking cessation and COPD. Eur Respir Rev. 2013;22(127):37-43. http://err.ersjournals.com/content/ errev/22/127/37.full.pdf

15. Sociedade Brasileira de Pneumologia e Tisiologia. Manual de Condutas e Práticas em Tabagismo. São Paulo: AC Farmacêutica; 2012.

16. Hoogendoorn M, Feenstra TL, Hoogenveen RT, Rutten-van Mölken MP. Long-term effectiveness and cost-effectiveness of smoking cessation interventions in patients with COPD. Thorax. 2010 Aug;65(8):711-8. https://thorax.bmj.com/content/thoraxjnl/65/8/711 full.pdf

17. Mendes KDS, Silveira RCCP, Galvão CM. Revisão integrativa: método de pesquisa para a incorporação de evidências na saúde $e$ na enfermagem. Texto \& Contexto Enfermagem. 2008;17(4):758-64.

18. Grant MJ, Booth A. A typology of reviews: an analysis of 14 review types and associated methodologies Health Info Libr J. 2009 Jun;26(2):91-108. http://dx.doi.org/10.1111/j.1471 1842.2009.00848.x

19. Broome ME. Integrative literature reviews for the development of concepts. In: Rodgers BL, Knafl KA, editors. 2nd ed. Concept Development in Nursing. Philadelphia, PA: W. B. Saunders Co., 1993. p. 231-250.

20. Jiménez-Ruiz CA, Andreas S, Lewis KE, Tonnesen P, van Schayck, Hajek P, Tonstad S., et al. Statement on smoking cessation in COPD and other pulmonary diseases and in smokers with comorbidities who find it difficult to quit. Eur Respir J. 2015;46(1):61-79. http://erj. ersjournals.com/content/46/1/61

21. Arancibia F. Enfermedad Pulmonar Obstructiva Crónicay Tabaquismo Rev Chil Enferm Respir. 2017;33(3):225-229. https://scielo.conicyt.cl/ scielo.php?script=sci_arttext\&pid=S0717-73482017000300225

22. Jiménez Ruiz CA, Buljubasich D, Riesco Miranda JA, Acuña Iscaray A, da Granda Orive JI, Chatkin JM, et al. Using PICO Methodology to Answer Questions About Smoking in COPD Patients. Arch Bronconeumol. 2017;53(11):622-628. Available from: http://dx.doi. org/10.1016/j.arbres.2017.04.012

23. Ussher M, Kakar G, Hajek P, West R. Dependence and motivation to stop smoking as predictors of success of a quit attempt among smokers seeking help to quit. Addict Behav. 2016;53:175-80. https:// core.ac.uk/download/pdf/82759925.pdf

24. Martin-Lujan F, Piñol-Moreso JLI Martin-Vergara NM, Basora-Gallisa $\mathrm{J}$, Pascual-Palacios I, et al. Effectiveness of a structured motivational intervention including smoking cessation advice and spirometry information in the primary care setting: the ESPITAP study. BMC Public Health. 2011;11:859. https://www.ncbi.nlm.nih.gov/pmc/ articles/PMC3236011/pdf/1471-2458-11-859.pdf

25. Hughes JR, Naudb S. Perceived role of motivation and selfefficacy in smoking cessation: A secondary data analysis. Addict Behav. 2016;61:58-61. https://www.ncbi.nlm.nih.gov/pmc/articles/ PMC4943656/pdf/nihms791085.pdf

26. Irizar-Aramburu MI, Martínez-Eizaguirre JM, Pacheco-Bravo, DiazAtienza M, Aguirre-Arratibel I, et al. Effectiveness of spirometry as a motivational tool for smoking cessation: a clinical trial, the ESPIMOAT study. BMC Fam Pract. 2013,14:185. https://www.ncbi. nlm.nih.gov/pmc/articles/PMC4028857/pdf/1471-2296-14-185.pdf

27. Parker DR, Eltinge S, Rafferty C, Eaton CB, Clarke J, Goldman RE. Primary care providers' views on using lung age as an aid to smoking cessation counseling for patients with chronic obstructive pulmonary disease. Lung. 2015;193(3):321-7. https://www.ncbi.nlm.nih.gov/ pmc/articles/PMC4433592/pdf/nihms673990.pdf

28. Heatherton TF, Kozlowski LT, Frecker RC, Fagerström KO. The Fagerström Test for Nicotine Dependence: a revision of the Fagerström Tolerance Questionnaire. $\mathrm{Br} J$ Addict. 1991;86(9):1119-27. $\quad$ https://pdfs.semanticscholar.org/74c8/ dd44c488807e054a5ed8711f6bc7b2fbeaea.pdf

29. Fagerström K. Determinants of tobacco use and renaming the FTND to the Fagerström Test for Cigarette Dependence. Nicotine Tob Res. 2012;14(1):75-8. https://nicotinepolicy.info/documents/research/ Fager\%20Determin\%20Renaming\%20FTND.pdf

30. Prochaska JO, DiClemente CC. Transtheoretical therapy: Toward a more integrative model of change. Psych Theory Res Pract. 1982;19(3):276-88. http://dx.doi.org/10.1037/h0088437

31. Masefield S, Powell $P$, Jiménez-Ruiz $C$, Hajek $P$, Lewis $K$, Andreas $S$, et al. Recommendations to improve smoking cessation outcomes from people with lung conditions who smoke. ERJ Open Res. 2016;2(2). pii: 00009-2016. https://www.ncbi.nlm.nih.gov/pmc/ articles/PMC5005168/

32. Awaisu A, Nik Mohamed MH, Mohamad Noordin N, Abd Aziz N, Syed Sulaiman SA, Muttalif AR, et al. The SCIDOTS Project: evidence of benefits of an integrated tobacco cessation intervention in tuberculosis care on treatment outcomes. Subst Abuse Treat Prev Policy. 2011;6:26. https://www.ncbi.nlm.nih.gov/pmc/articles/ PMC3196696/pdf/1747-597X-6-26.pdf

33. van Eerd EAM, van der Meer RM, van Schayck OC, Kotz D. Smoking cessation for people with chronic obstructive pulmonary disease. Cochrane Database Syst Rev. 2016;(8):CD010744. https://www. ncbi.nlm.nih.gov/pubmed/27545342

34. Wagena EJ, Knipschild PG, Huibers MJ, Wouters EF, van Schayck $\mathrm{CP}$. Efficacy of bupropion and nortriptyline for smoking cessation among people at risk for or with chronic obstructive pulmonary disease. Arch Intern Med. 2005;165(19):2286-92. https:// jamanetwork.com/journals/jamainternalmedicine/fullarticle/486760

35. Chatkin JM, Dullius CR. The management of asthmatic smokers. Asthma Res Pract. 2016;2:10. https://asthmarp.biomedcentral.com/ track/pdf/10.1186/s40733-016-0025-7

36. Cahill K, Lindson-Hawley N, Thomas KH, Fanshawe TR, Lancaster T. Nicotine receptor partial agonists for smoking cessation. Cochrane Database Syst Rev. 2016;(5):CD006103. https://www.ncbi.nlm.nih gov/pubmed/27158893

37. European Network for Smoking and Tobacco Prevention (ENSP) [homepage on the Internet]. Brussels: ENSP; c2016 [cited 2018 Sep 2]. ENSP Guidelines for treating tobacco dependence. [Adobe Acrobat document, 156 p.]. Available from: http://elearning-ensp.eu/ assets/English\%20version.pdf

38. Brasil. Ministério da Saúde [homepage on the Internet]. Brasília: Ministério da Saúde; c2015 [cited 2018 Sept 2]. Estratégias para cuidado da pessoa com doença crônica: o cuidado da pessoa tabagista. Cad Atenção Básica. 2015;40. [Adobe Acrobat document, 156 p.]. Available from: http://189.28.128.100/dab/docs/portaldab/ publicacoes/caderno_40.pdf

39. National Comprehensive Cancer Network (NCCN) [homepage on the Internet]. Brussels: NCCN; c2017 [updated 2017 Aug 21; cited 2018 Sept 2]. Clinical Practice Guidelines in Oncology (NCCN Guidelines). Smoking Cessation. [Adobe Acrobat document, 66 p.]. Available 
from: http://oncolife.com.ua/doc/nccn/Smoking_Cessation.pdf

40. Jiménez-Ruiz CA, Garcia Rueda M, Martinez Muñiz MA, Sellarés $J$, Jiménez-Fuentes MA, Lázaro Asegurado $L$, et al. Varenicline in smokers with severe or very severe COPD after 24 weeks of treatment. A descriptive analysis: VALUE study. Monaldi Arch Chest Dis. 2017;87(3):874. Available from: https://www.monaldi-archives org/index.php/macd/article/view/874/801

41. Kotz D, Viechtbauer W, Simpson CR, van Schayck OCP, West R, Sheikh A. Cardiovascular and neuropsychiatric risks of varenicline and bupropion in smokers with chronic obstructive pulmonary disease. Thorax. 2017;72(10):905-911. Available from: https://thorax bmi.com/content/72/10/905

42. Cahill K, Stevens S, Perera R, Lancaster T. Pharmacological interventions for smoking cessation: an overview and network meta-analysis. Cochrane Database Syst Rev. 2013(5):CD009329. Available from: http://tobacco.cochrane.org/sites/tobacco.cochrane. org/files/public/uploads/UKNSCC\%202015\%20summaries-\%20 pharmacological.pdf

43. Chang PH, Chiang CH, Ho WC, Wu PZ, Tsai JS, Guo FR. Combination therapy of varenicline with nicotine replacement therapy is bette than varenicline alone: a systematic review and meta-analysis of randomized controlled trials. BMC Public Health. 2015;15:689. Available from: https://bmcpublichealth.biomedcentral.com/track/ pdf/10.1186/s12889-015-2055-0

44. Burke H, Leonardi-Bee J, Hashim A, Pine-Abata H, Chen Y, Cook DG, et al. Prenatal and passive smoke exposure and incidence of asthma and wheeze: systematic review and meta-analysis. Pediatrics. 2012;129(4):735-44. https://doi.org/10.1542/peds.2011-2196

45. Gilliland FD, Berhane K, Li YF, Rappaport EB, Peters JM. Effects of early onset asthma and in utero exposure to maternal smoking on childhood lung function. Am J Respir Crit Care Med. 2003;167(6):91724. https://doi.org/10.1164/rccm.200206-6160C

46. Silvestri M, Franchi S, Pistorio A, Petecchia L, Rusconi F. Smoke exposure, wheezing, and asthma development: a systematic review and meta-analysis in unselected birth cohorts. Pediatr Pulmonol. 2015;50(4):353-62. https://doi.org/10.1002/ppul.23037

47. Godtfredsen NS, Lange P, Prescott E, Osler M, Vestbo J. Changes in smoking habits and risk of asthma: a longitudinal population based study. Eur Respir J. 2001;18(3):549-54. https://doi.org/10.1183/0903 1936.01.00100801

48. Polosa R, Knoke JD, Russo C, Piccillo G, Caponnetto P, Sarvà M et al. Cigarette smoking is associated with a greater risk of incident asthma in allergic rhinitis. J Allergy Clin Immunol. 2008;121(6):142834. https://doi.org/10.1016/j.jaci.2008.02.041

49. Nakamura K, Nagata C, Fujii K, Kawachi T, Takatsuka N, Oba S, et al. Cigarette smoking and the adult onset of bronchial asthma in Japanese men and women. Ann Allergy Asthma Immunol. 2009;102(4):288-93. https://doi.org/10.1016/S1081-1206(10)60333-X

50. Cardoso TA, Roncada C, Silva ERD, Pinto LA, Jones MH, Stein RT, et al. The impact of asthma in Brazil: a longitudinal analysis of data from a Brazilian national database system. J Bras Pneumol. 2017;43(3):163168. https://doi.org/10.1590/s1806-37562016000000352

51. Lange P, Parner J, Vestbo J, Schnohr P, Jensen G. A 15-year follow-up study of ventilatory function in adults with asthma. N Engl J Med. 1998;339(17):1194-200. https://doi.org/10.1056/ NEJM199810223391703

52. Zheng X, Guan W, Zheng J, Ye P, Liu S, Zhou J, et al. Smoking influences response to inhaled corticosteroids in patients with asthma: a meta-analysis. Curr Med Res Opin. 2012;28(11):1791-8. https://doi.org/10.1185/03007995.2012.722991

53. Chalmers GW, Macleod KJ, Little SA, Thomson LJ, McSharry $\mathrm{CP}$, Thomson NC. Influence of cigarette smoking on inhaled corticosteroid treatment in mild asthma. Thorax. 2002;57(3):226-30. https://doi.org/10.1136/thorax.57.3.226

54. Lazarus SC, Chinchilli VM, Rollings NJ, Boushey HA, Cherniack R Craig TJ, et al. Smoking affects response to inhaled corticosteroids or leukotriene receptor antagonists in asthma. Am J Respir Crit Care Med. 2007;175(8):783-90. https://doi.org/10.1164/rccm.200511$17460 \mathrm{C}$

55. Chaudhuri R, Livingston E, McMahon AD, Thomson L, Borland W, Thomson NC. Cigarette smoking impairs the therapeutic response to oral corticosteroids in chronic asthma. Am J Respir Crit Care Med. 2003;168(11):1308-11. https://doi.org/10.1164/rccm.200304-5030C

56. Boulet LP, FitzGerald JM, Mclvor RA, Zimmerman S, Chapman KR Influence of current or former smoking on asthma management and control. Can Respir J. 2008;15(5):275-9. https://doi. org/10.1155/2008/725074
57. Thomson NC, Chaudhuri R. Asthma in smokers: challenges and opportunities. Curr Opin Pulm Med. 2009;15(1):39-45. https://doi. org/10.1097/MCP.0b013e32831da894

58. Chaudhuri R, McSharry C, McCoard A, Livingston E, Hothersall E, Spears $M$, et al. Role of symptoms and lung function in determining asthma control in smokers with asthma. Allergy. 2008;63(1):132-5. https://doi.org/10.1111/j.1398-9995.2007.01538.x

59. U.S. Department of Health and Human Services. Public Health Service. Centers for Disease Control. Center for Chronic Disease Prevention and Health Promotion. Office on Smoking and Health. The Health Benefits of Smoking Cessation-a report of the Surgeon General. DHHS Publication No. (CDC) 90-8416. Rockville (MD): CDC 1990.

60. Chopra GS. Studies on psycho-clinical aspects of long-term marihuana use in 124 cases. Int J Addict. 1973;8(6):1015-26. https:// doi.org/10.3109/10826087309033103

61. Chatkin JM, Zani-Silva L, Ferreira I, Zamel N. Cannabis-Associated Asthma and Allergies. Clin Rev Allergy Immunol. 2019;56(2):196206. https://doi.org/10.1007/s12016-017-8644-1

62. Chatkin JM, Zabert G, Zabert I, Chatkin G, Jiménez-Ruiz CA, de Granda-Orive Jl, et al. Lung Disease Associated with Marijuana Use. Arch Bronconeumol. 2017;53(9):510-515. https://doi.org/10.1016/j. arbres.2017.03.019

63. Gaeta TJ, Hammock R, Spevack TA, Brown $H$, Rhoden $K$ Association between substance abuse and acute exacerbation of bronchial asthma. Acad Emerg Med. 1996; 3:1170-2. https://doi. org/10.1111/j.1553-2712.1996.tb03386.x

64. Caponnetto P, Auditore R, Russo C, Alamo A, Campagna D, Demma $S$, et al. "Dangerous relationships": asthma and substance abuse. J Addict Dis. 2013;32(2):158-67. https://doi.org/10.1080/10550887. 2013.795469

65. Decuyper II, Faber MA, Sabato V, Bridts CH, Hagendorens MM, Rihs $\mathrm{HP}$, et al. Where there's smoke, there's fire: cannabis allergy through passive exposure. J Allergy Clin Immunol Pract. 2017:5(3):864-865. https://doi.org/10.1016/j.jaip.2016.10.019

66. McLeish AC, Zvolensky MJ. Asthma and cigarette smoking: a review of the empirical literature. J Asthma. 2010;47(4):345-61. https://doi. org/10.3109/02770900903556413

67. Perret JL, Bonevski B, McDonald CF, Abramson MJ. Smoking cessation strategies for patients with asthma: improving patient outcomes. J Asthma Allergy. 2016;9:117-28. https://doi.org/10.2147/ JAA.S85615

68. Bush T, Zbikowski SM, Mahoney L, Deprey M, Mowery P, Cerutti B. State quitlines and cessation patterns among adults with selected chronic diseases in 15 states, 2005-2008. Prev Chronic Dis. 2012;9:E163. https://doi.org/10.5888/pcd9.120105

69. McLeish AC, Johnson AL, Avallone KM, Zvolensky MJ. Evaluating the role of anxiety sensitivity in barriers to cessation and reasons for quitting among smokers with asthma. Psychol Health Med 2016;21(2):236-47. https://doi.org/10.1080/13548506.2015.1051058

70. Global Initiative for Chronic Obstructive Lung Disease. Global strategy for the diagnosis, management, and prevention of chronic obstructive pulmonary disease. Updated 2018. Bethesda: Global Initiative for Chronic Obstructive Lung Disease; 2018.

71. U.S. Department of Health and Human Services. Public Health Service. Office of the Surgeon General [homepage on the Internet]. Rockville (MD): U.S. Department of Health and Human Services The Health Consequences of Smoking: 50 Years of Progress. A Report of the Surgeon General. Atlanta (GA): U.S. Department of Health and Human Services, Centers for Disease Control and Prevention, National Center for Chronic Disease Prevention and Health Promotion, Office on Smoking and Health; 2014. [Adobe Acrobat document, 1081p.]. Available from: https://www.surgeongeneral. gov/library/reports/50-years-of-progress/full-report.pdf

72. Liu S, Zhou Y, Liu S, Chen X, Zou W, Zhao D, et al. Association between exposure to ambient particulate matter and chronic obstructive pulmonary disease: results from a cross-sectiona study in China. Thorax. 2017:72(9):788-795. https://doi.org/10.1136/ thoraxjnl-2016-208910

73. Moreira MA, Barbosa MA, Jardim JR, Queiroz MC, Inácio LU Doença pulmonar obstrutiva crônica em mulheres expostas à fumaça de fogão e lenha. Rev Assoc Med Bras (1992). 2013;59(6):607-13. https://doi.org/10.1016/j.ramb.2013.09.001

74. Sana A, Somda SMA, Meda N, Bouland C. Chronic obstructive pulmonary disease associated with biomass fuel use in women: a systematic review and meta-analysis. BMJ Open Respir Res. 2018;5(1):e000246. https://doi.org/10.1136/bmjresp-2017-000246 
75. Bahtt S, Kim Y, Harrington K, Lutz SM, Cho MH, DeMeo DL, et al. Smoking duration alone provides stronger risk estimates of chronic pulmonary obstructive disease than pack-years. Thorax. 2018;73(5):414-421. https://doi.org/10.1136/thoraxjnl-2017-210722

76. Queiroz MC, Moreira MA, Rahabi MF. Underdiagnosis of COPD at primary health care clinics in the city of Aparecida de Goiânia, Brazil. J Bras Pneumol. 2012;38(6):692-9. https://doi.org/10.1590/S180637132012000600003

77. Moreira GL, Manzano BM, Gazzotti MR, Nascimento OA, PerezPadilla R, Menezes AM, et al. PLATINO, a nine-year follow-up study of COPD in the city of São Paulo, Brazil: the problem of underdiagnosis. J Bras Pneumol. 2014;40(1):30-7. https://doi. org/10.1590/S1806-37132014000100005

78. Menezes AM, Perez-Padilla R, Jardim JR, Mui-o A, Lopez MV, Valdivia $\mathrm{G}$, et al. Chronic obstructive disease in five Latin American cities (the PLATINO study): a prevalence study. Lancet. 2005;366(9500):187581. https://doi.org/10.1016/S0140-6736(05)67632-5

79. Lundbäck $B$, Lindberg $A$, Lindström $M$, et al. Not 15 but $50 \%$ of smokers develop COPD?-Report from the Obstructive Lung Disease in Northern Sweden Studies. Respir Med. 2003;97(2):15522. https://doi.org/10.1053/rmed.2003.1446

80. Rennard S, Vestbo J. COPD: the dangerous underestimate of $15 \%$ Lancet 2006;367(9518):1216-9. https://doi.org/10.1016/S01406736(06)68516-4

81. Corrêa PC, Barreto SM, Passos VM. Smoking-attributable mortality and years of potential life lost in 16 Brazilian capitals, 2003: prevalence-based study. BMC Public Health. 2009;9:206. https://doi. org/10.1186/1471-2458-9-206

82. de São José BP, Corrêa RA, Malta DC, Passos VMA, França EB, Teixeira RA, et al. Mortality and disability from tobacco-related diseases in Brazil, 1990 to 2015. Rev Bras Epidemiol. 2017;20(Supp 1):75-89. https://doi.org/10.1590/1980-5497201700050007

83. Stelmach R, Fernandes FL, Carvalho-Pinto RM, Athanazio RA, Rached SZ, Prado GF, et al. Comparison between objective measures of smoking and self-reported smoking status in patients with asthma or COPD: are our patients telling us the truth? J Bras Pneumol. 2015;41(2):124-32. https://doi.org/10.1590/S180637132015000004526

84. van Eard EA, van Rossem CR, Spigt MG, Wesseling G, van Schayck OC, Kotz D. Do we need tailored smoking cessation interventions for smokers with COPD? A comparative study of smokers with and without regarding factors associated with tobacco smoking Respiration. 2015;90(3):211-9. https://doi.org/10.1159/000398816

85. Tøttenborg SS, Thomsen RW, Johnsen SP, Nielsen $H$, Lange $P$. Determinants of Smoking Cessation in Patients With COPD Treated in the Outpatient Setting. Chest. 2016;150(3):554-62. https://doi. org/10.1016/j.chest.2016.05.020

86. Schauer GL, Wheaton AG, Malarcher AM Croft JB. Health-care Provider Screening and Advice for Smoking Cessation Among Smokers With and Without COPD: 2009-2010 National Adult Tobacco Survey. Chest. 2016;149(3):676-84 https://doi.org/10.1378/ chest.14-2965

87. Martínez-González C, Casanova C, de-Torres JP, Marín JM, de Lucas P, Fuster A, et al. Changes and Clinical Consequences of Smoking Cessation in Patients With COPD: A Prospective Analysis From the CHAIN Cohort. Chest. 2018;154(2):274-285. https://doi. org/10.1016/j.chest.2018.02.007

88. Bai JW, Chen XX, Liu S, Yu L, Xu J. Smoking cessation affects the natural history of COPD. Int J Chron Obstruct Pulmon Dis. 2017;12:3323-3328. https://doi.org/10.2147/COPD.S150243

89. Tønnesen P, Mikkelsen K, Bremann L. Nurse-conducted smoking cessation in patients with COPD using nicotine sublingual tablets and behavioral support. Chest. 2006;130(2):334-42. https://doi. org/10.1378/chest.130.2.334

90. Godtfredsen NS, Vestbo J, Osler M, Prescott E. Risk of hospital admission for COPD following smoking cessation and reduction: a Danish population study. Thorax. 2002;57(11):967-72. https://doi. org/10.1136/thorax.57.11.967

91. Anthonisen NR, Connet J, Murray RP. Smoking and lung function of Lung Health Study participants after 11 years. Am J Respir Crit Care Med. 2002;166(5):675-9. https://doi.org/10.1164/rccm.2112096

92. Anthonisen NR, Skeans MA, Wise RA, Manfreda J, Kanner RE, Connett JE; et al. The effects of a smoking cessation intervention on 14.5-year mortality: a randomized clinical trial. Ann Intern Med. 2005;142(4):233-9. $\quad$ https://doi.org/10.7326/0003-4819-142-4 200502150-00005
93. Drope J, Schluger N, editors [monograph on the Internet]. 6th ed. The Tobacco Atlas. Atlanta: American Cancer Society and Vital Strategies; 2018. [Adobe Acrobat document, 58p.]. Available from: https://tobaccoatlas.org/wp-content/uploads/2018/03/ TobaccoAtlas_6thEdition_LoRes_Rev0318.pdf

94. Rodgman A, Perfetti TA. Alphabetical Component Index. In: Rodgman A, Perfetti TA, editors. The Chemical Components of Tobacco and Tobacco Smoke. Boca Raton (FL): CRC Press; 2008. p. 1483-4. https://doi.org/10.1201/9781420078848

95. IARC Working Group on the Evaluation of Carcinogenic Risks to Humans. Tobacco smoke and involuntary smoking. IARC Monogr Eval Carcinog Risks Hum. 2004;83:1-1438.

96. Balogh EP, Dresler C, Fleury ME, Gritz ER, Kean TJ, Myers ML, et al. Reducing tobacco-related cancer incidence and mortality: summary of an institute of medicine workshop. Oncologist. 2014;19(1):21-31. https://doi.org/10.1634/theoncologist.2013-0230

97. IARC Working Group on the Evaluation of Carcinogenic Risks to Humans. International Agency for Research on Cancer. Personal habits and indoor combustions. Volume $100 \mathrm{E}$. A review of human carcinogens. IARC Monogr Eval Carcinog Risks Hum. 2012;100(Pt E): $1-538$.

98. Álvarez FV, Trueba IM, Sanchis JB, López-Rodó LM, Rodríguez Suárez PM, de Cos Escuín JS, et al. Recommendations of the Spanish Society of Pneumology and Thoracic Surgery on the diagnosis and treatment of non-small-cell lung cancer. Arch Bronconeumol. 2016;52 Suppl 1:2-62.

99. Menezes AM, Horta BL, Oliveira AL, Kaufmann RA, Duquia $R$, Diniz $A$, et al. Attributed risk to smoking for lung cancer, laryngeal cancer and esophageal cancer [Article in Portuguese]. Rev Saude Publica. 2002;36(2):129-34. https://doi.org/10.1590/S003489102002000200002

100. Araujo LH, Baldotto C, Castro G Jr, Katz A, Ferreira CG, Mathias C, et al. Lung cancer in Brazil. J Bras Pneumol. 2018:44(1):55-64 https://doi.org/10.1590/s1806-37562017000000135

101. Azevedo E Silva G, de Moura L, Curado MP, Gomes Fda S, Otero $\mathrm{U}$, Rezende LF, et al. The Fraction of Cancer Attributable to Ways of Life, Infections, Occupation, and Environmental Agents in Brazil in 2020. PLoS One. 2016;11(2):e0148761. https://doi.org/10.1371/ journal.pone. 0148761

102. Parsons A, Daley A, Begh R, Aveyard P. Influence of smoking cessation after diagnosis of early stage lung cancer on prognosis: Systematic review of observational studies with meta-analysis. BMJ. 2010;340:b5569. https://doi.org/10.1136/bmj.b5569

103. Karam-Hage M, Cinciripini PM, Gritz ER. Tobacco use and cessation for cancer survivors: An overview for clinicians. CA Cancer J Clin. 2014;64(4):272-90. https://doi.org/10.3322/caac.21231

104. Sardari Nia P, Weyler J, Colpaert C, Vermeulen P, Van Marck E, Van Schil P. Prognostic value of smoking status in operated nonsmall cell lung cancer. Lung Cancer. 2005;47(3):351-9. https://doi. org/10.1016/j.lungcan.2004.08.011

105. Cinciripini P. Smoking Cessation in Patients with Cancer: Treatment Advances and the Oncologist's Role. J Natl Canc Netw. 2017;15(5):748-50. https://doi.org/10.6004/jnccn.2017.0091

106. Gritz ER, Toll BA, Warren GW. Tobacco use in the oncology setting: advancing clinical practice and research. [Internet] Cancer Epidemio Biomarkers Prev. 2014;23(1):3-9. https://doi.org/10.1158/1055-9965. EPI-13-0896

107. American Society of Clinical Oncology [monograph on the Internet]. Tobacco Cessation Guide for Oncology Providers. Alexandria (VI): ASCO; 2012. [Adobe Acrobat document, 36p.]. Available from: https://moqc.org/wp-content/uploads/2017/08/ASCO-_TobaccoCessation-Guide-for-Oncology-Providers.pdf

108. Shields PG, Herbst RS, Arenberg D, Benowitz NL, Bierut L, Luckart JB, et al. Smoking Cessation, Version 1.2016, NCCN Clinical Practice Guidelines in Oncology. J Natl Compr Canc Netw. 2016;14(11):14301468. https://doi.org/10.6004/jnccn.2016.0152

109. Koshiaris C, Aveyard P, Oke J, Ryan R, Szatkowski L, Stevens R, et al. Smoking cessation and survival in lung, upper aero-digestive tract and bladder cancer: cohort study Br J Cancer. 2017;117(8):12241232. https://doi.org/10.1038/bjc.2017.179

110. World Health Organization. Global tuberculosis report 2017 Geneva: World Health Organization; 2017.

111. Brasil. Ministério de Saúde. Secretaria de Vigilância em Saúde. Departamento de Vigilância das Doenças Transmissíveis. Panorama da Tuberculose no Brasil: A mortalidade em números. Brasília: Ministério de Saúde; 2016. [Adobe Acrobat document, 128p.]. 
Available from: http://portalarquivos2.saude.gov.br/images/pdf/2016/ outubro/15/panorama_tuberculose_brasil_mortalidade.pdf

112. World Health Organization. Fact Sheets on Tuberculosis. Geneva: World Health Organization; 2017. Available from: http://www.who. int/tb/publications/factsheet_global.pdf?ua $=1$

113. Webb G. The effect of the inhalation of cigarette smoke on the lungs: A clinical study. Am Rev Tuberc. 1918;2(1):25-7.

114. World Health Organization; International Union Against Tuberculosis and Lung Diseases. A WHO/The Union monograph on TB and tobacco control: joining efforts to control two related global epidemics. Geneva: WHO; 2007.

115. International Union Against Tuberculosis and Lung Diseases. Smoking Cessation and Smoke-free Environments for Tuberculosis Patients. Paris: International Union Against Tuberculosis and Lung Diseases; 2010.

116. Prasad R, Garg R, Singhal S, Dawar R, Agarwal GG. A case-control study of tobacco smoking and tuberculosis in India. Ann Thorac Med. 2009;4(4):208-10. https://doi.org/10.4103/1817-1737.56007

117. Bates MN, Khalakdina A, Pai M, Chang L, Lessa F, Smith KR. Risk of tuberculosis from exposure to tobacco smoke: a systematic review and meta-analysis. Arch Intern Med. 2007;167(4):335-42. https://doi. org/10.1001/archinte.167.4.335

118. Gajalakshmi V, Peto R, Kanaka TS, Jha P. Smoking and mortality from tuberculosis and other diseases in India: retrospective study of 43000 adult male deaths and 35000 controls. Lancet. 2003;362(9383):50715. https://doi.org/10.1016/S0140-6736(03)14109-8

119. Slama K, Chiang CY, Enarson DA, Hassmiller K, Fanning A, Gupta P, et al. Tobacco and tuberculosis: a qualitative systematic review and meta-analysis. Int J Tuberc Lung Dis. 2007;11(10):1049-61 .

120. Narasimhan P, Wood J, Macintyre CR, Mathai D. Risk factors for tuberculosis. Pulm Med. 2013;2013:828939. https://doi. org/10.1155/2013/828939

121. Sopori M. Effects of cigarette smoke on the immune system. Nat Rev Immunol. 2002;2(5):372-7. https://doi.org/10.1038/nri803

122. Wang H. Yu M, Ochani M, Amella CA, Tanovic M, Susarla S, et al. Nicotinic acetylcholine receptor alpha7 subunit is an essential regulator of inflammation. Nature. 2003;421(6921):384-8. https://doi org/10.1038/nature01339

123. Ernst JD. The immunological life cycle of tuberculosis. Nat Rev Immunol. 2012;12(8):581-91. https://doi.org/10.1038/nri3259

124. Feng $Y$, Kong $Y$, Barnes PF, Huang FF, Klucar $P$, Wang $X$, et al. Exposure to cigarette smoke inhibits the pulmonary $T$-cell response to influenza virus and Mycobacterium tuberculosis. Infect Immun. 2011;79(1):229-37. https://doi.org/10.1128/IAl.00709-10

125. Shang S, Ordway D, Henao-Tamayo M, Bail X, Oberley-Deegan $R$, Shanley $C$, et al. Cigarette smoke increases susceptibility to tuberculosis-evidence from in vivo and in vitro models. J Infect Dis. 2011:203(9):1240-8. https://doi.org/10.1093/infdis/jir009

126. Arcavi L, Benowitz NL. Cigarette smoking and infection. Arch Intern Med. 2004;164(20):2206-16. https://doi.org/10.1001/ archinte.164.20.2206

127. Tipayamongkholgul $M$, Podhipak $A$, Chearskul S, Sunakorn $P$. Factors associated with the development of tuberculosis in BCG immunized children. Southeast Asian J Trop Med Public Health. 2005;36(1):145-50

128. Altet-Gomez MN, Alcaide J, Plans P, Taberner JL, Salto E, Folguera $\mathrm{LI}$, et al. Passive smoking and risk of pulmonary tuberculosis in children immediately following infection. A case-control study. Tuber Lung Dis. 1996;77(6):537-44. https://doi.org/10.1016/S09628479(96)90052-0

129. Ariyothai N, Podhipak A, Akarasewi P, Tornee S, Smith-Karn S Thongprathum P. Cigarette smoking and its relation to pulmonary tuberculosis in adults. Southeast Asian J Trop Med Public Health. 2004;35(1):219-27.

130. Altet-Gômez MN, Alcaide J, Godoy P, Romero MA, Hernández del Rey I. Clinical and epidemiological aspects of smoking and tuberculosis: a study of 13,038 cases. Int J Tuberc Lung Dis. 2005;9(4):430-6.

131. Thomas A, Gopi PG, Santha T, Chandrasekaran V, Subramani $R$, Selvakumar $N$, et al. Predictors of relapse among pulmonary tuberculosis patients treated in a DOTS programme in South India. Int J Tuberc Lung Dis. 2005;9(5):556-61.

132. d'Arc Lyra Batista J, de Fátima Pessoa Militão de Albuquerque M, de Alencar Ximenes RA, Rodrigues LC. Smoking increases the risk of relapse after successful tuberculosis treatment. Int J Epid 2008;37(4):841-51. https://doi.org/10.1093/ije/dyn113
133. Cailleaux-Cesar M, Loredo C, Lapa e Silva JR, Conde MB. Impact of smoking on sputum culture conversion and pulmonary tuberculosis treatment outcomes in Brazil: a retrospective cohort study. J Bras Pneumol. 2018;44(2):91-105. https://doi.org/10.1590/s180637562017000000161

134. Wen CP, Chan TC, Chan HT, Tsai MK, Cheng TY, Tsai SP. The reduction of tuberculosis risks by smoking cessation. BMC Infect Dis. 2010;10:156. https://doi.org/10.1186/1471-2334-10-156

135. GBD 2016 Risk Factors Collaborators. Global, regional, and nationa comparative risk assessment of 84 behavioural, environmental and occupational, and metabolic risks or clusters of risks, 1990-2016: a systematic analysis for the Global Burden of Disease Study 2016. Lancet. 2017;390(10100):1345-1422. https://doi.org/10.1016/S0140 6736(17)32366-8

136. Institute for Health Metrics and Evaluation (IHME) [homepage on the Internet]. Seattle (WA): IHME; [cited 2018 Aug 26]. Brazil. [about 13 screens]. Available from: http://www.healthdata.org/brazil

137. Nemmar A, Holme JA, Rosas I, Schwarze PE, Alfaro-Moreno E Recent Advances in particulate matter and nanoparticle toxicology: a review of the in vivo and in vitro studies. Biomed Res Int. 2013;2013: 279371. https://doi.org/10.1155/2013/279371

138. World Health Organization [homepage on the Internet]. Geneva: WHO; [updated 2018, cited 2016 Jun 1]. Air pollution [about 3 screens]. Available from: http://www.who.int/airpollution/data/en/

139. Pope CA 3rd, Burnett RT, Turner MC, Cohen A, Krewski D, Jerrett $M$, et al. Lung cancer and cardiovascular disease mortality associated with ambient air pollution and cigarette smoke: shape of the exposure-response relationships. Environ Health Perspect. 2011;119(11):1616-21. https://doi.org/10.1289/ehp.1103639

140. Nishinakagawa T, Senjyu H, Tanaka T, Asai M, Kotaki K, Yano Y, et al. Smoking aggravates the impaired pulmonary function of officially acknowledged female victims of air pollution of 40 years ago. Tohoku J Exp Med. 2014;234(2):151-60. https://doi.org/10.1620/ tjem.234.151

141. Tan CE, Glantz SA. Association between smoke-free legislation and hospitalizations for cardiac, cerebrovascular, and respiratory diseases: a meta-analysis. Circulation. 2012;26(8):2177-83. https:// doi.org/10.1161/CIRCULATIONAHA.112.121301

142. Thun MJ, Carter BD, Feskanich D, Freedman ND, Prentice $R$ Lopez AD, Hartge P, Gapstur SM. 50-year trends in smoking-related mortality in the United States. N Engl J Med. 2013;368(4):351-64 https://doi.org/10.1056/NEJMsa1211127

143. Hessel PA, Gamble JF, Nicolich M. Relationship between silicosis and smoking. Scand J Work Environ Health. 2003;29(5):239-36. https://doi.org/10.5271/sjweh.739

144. Tse LA, Yu IT, Oiu H, Leung CC. Joint effects of smoking and silicosis on diseases to the lungs. PLoS One. 2014;9(8):e104494. https://doi.org/10.1371/journal.pone.0104494

145. GBD 2016 Causes of Death Collaborators. Global, regional, and national age-sex specific mortality for 264 causes of death, 19802016: a systematic analysis for the Global Burden of Disease Study 2016. Lancet. 2017;390(10100):1151-1210. https://doi.org/10.1016/ S0140-6736(17)32152-9

146. GBD 2016 Disease and Injury Incidence and Prevalence Collaborators. Global, regional, and national incidence, prevalence, and years lived with disability for 328 diseases and injuries for 195 countries, 1990-2016: a systematic analysis for the Global Burden of Disease Study 2016. Lancet. 2017;390(10100):1211-1259. https:// doi.org/10.1016/S0140-6736(17)32154-2

147. Syamlal G, King BA, Mazurek JM. Tobacco Use Among Working Adults - United States, 2014-2016. MMWR Morb Mortal Wkly Rep. 2017;66(42):1130-1135. https://doi.org/10.15585/mmwr.mm6642a2

148. Qian OZ, Cao XK, Shen FH, Wang O. Correlations of smoking with cumulative total dust exposure and cumulative abnormal rate of pulmonary function in coal-mine workers. Exp Ther Med. 2016;12(5):2942-2948. https://doi.org/10.3892/etm.2016.3700

149. Unalacak M, Altin R, Kart L, Tor M, Örnek T, Altunel H. Smoking prevalence, behavior and nicotine addiction among coal workers in Zonguldak, Turkey. J Occup Health. 2004;46(4):289-95. https://doi org/10.1539/joh.46.289

150. Mana-Salicio VA, Botelho C, Silva AM, Salicio MA. Factors associated with alterations in lung function among workers in the ceramics industry [Article in Portuguese]. Cien Saude Colet. 2013;18(5):13531360. https://doi.org/10.1590/S1413-81232013000500020

151. Doll R, Peto R. Boreham J, Sutherland I. Mortality in relation to smoking: 50 years' observations on male British doctors. BMJ. 
2004;328(7455):1519. https://doi.org/10.1136/bmj.38142.554479.AE

152. Verbiest $M$, Brakema $E$, van der Kleij $R$, Sheals $K$, Allistone $G$, Williams $S$, et al. National guidelines for smoking cessation in primary care: a literature review and evidence analysis. NPJ Prim Care Respir Med. 2017;27(1):2. https://doi.org/10.1038/s41533-016-0004-8

153. Vassallo R. Diffuse lung diseases in cigarette smokers Semin Respir Crit Care Med. 2012;33(5):533-42. https://doi. org/10.1055/s-0032-1325162

154. Margaritopoulos GA, Harari S, Caminati A, Antoniou KM. Smokingrelated idiopathic interstitial pneumonia: A review. Respirology. 2016;21(1):57-64. https://doi.org/10.1111/resp.12576

155. Margaritopoulos GA, Vasarmidi E, Jacob J, Wells AU, Antoniou KM. Smoking and interstitial lung diseases. Eur Respir Rev. 2015;24(137):428-35. https://doi.org/10.1183/16000617.0050-2015

156. Putman RK, Hatabu H, Araki T, Gudmundsson G, Gao W, Nishino $\mathrm{M}$, et al. Association Between Interstitial Lung Abnormalities and AllCause Mortality. JAMA. 2016;315(7):672-81. https://doi.org/10.1001/ jama.2016.0518

157. Sundram FX. Clinical studies of alveolar-capillary permeability using technetium-99m DTPA aerosol. Ann Nucl Med. 1995;9(4):171-8. https://doi.org/10.1007/BF03168397

158. Feldman C, Anderson R. Cigarette smoking and mechanisms of susceptibility to infections of the respiratory tract and other organ systems. J Infect. 2013;67(3):169-84. https://doi.org/10.1016/j. jinf.2013.05.004

159. Bhat TA, Kalathil SG, Bogner PN, Miller A, Lehmann PV, Thatcher TH, et al. Secondhand Smoke Induces Inflammations and Impairs Immunity to Respiratory Infections. J Immunol. 2018;200(8):29272940. https://doi.org/10.4049/jimmunol.1701417

160. De P, Farley A, Lindson N, Aveyard P. Systematic review and metaanalysis: influence of smoking cessation on incidence of pneumonia in HIV. BMC Med. 2013;11:15. https://doi.org/10.1186/1741-7015$11-15$

161. Feldman S. Varicella-zoster virus pneumonitis. Chest. 1994;106(1 Suppl):22S-27S. https://doi.org/10.1378/chest.106.1_ Supplement.22S

162. Murin S, Bilello KM. Respiratory tract Infections: another reason not to smoke. Cleve Clin J Med. 2005;72(10):916-20. https://doi. org/10.3949/ccjm.72.10.916

163. Lipsky BA, Boyco EJ, Inui TS, Koespsell TD. Risk factors for acquiring pneumococcal Infections. Arch Intern Med. 1986:146(11):2179-85. https://doi.org/10.1001/archinte.1986.00360230105016

164. Wewers MD, Diaz PT, Wewers ME, Lowe MP, Nagaraja HN, Clanton TL. Cigarette smoking in HIV infection induces a suppressive inflammatory environment in the lung. Am J Respir Crit Care Med. 1998;158(5 Pt 1):1543-9. https://doi.org/10.1164/ ajrccm.158.5.9802035

165. Correa RA, José BPS, Malta DC, Passos VMA, França EB, Teixeira RA, et al. Burden of disease by lower respiratory tract infections in Brazil, 1990 to 2015: estimates of the Global Burden of Disease 2015 study. Rev Bras Epidemiol. 2017;20Suppl 01(Suppl 01):171-181. https://doi.org/10.1590/1980-5497201700050014

166. Bates MN, Khalakdina A, Pai M, Chang L, Lessa F, Smith KR. Risk of tuberculosis from exposure to tobacco smoke: a systematic review and meta-analysis. Arch Intern Med. 2007;167(4):335-42. https://doi. org/10.1001/archinte.167.4.335

167. Barreto RB, Pincelli M, Steinwandter R, Silva AP, Manes J, Steidle LJ. Smoking among patients hospitalized at a university hospital in the south of Brazil: prevalence, degree of nicotine dependence, and motivational stage of change. J Bras Pneumol. $2012 ; 38(1): 72-80$ https://doi.org/10.1590/S1806-37132012000100011

168. Corrêa AP. Prevalência e perfil tabágico de pacientes adultos internados em unidades cirúrgicas de um hospital universitário. [dissertation]. Porto Alegre: Universidade Federal do Rio Grande do Sul; 2014. 86p. Available from: https://www.lume.ufrgs.br/bitstream/ handle/10183/98548/000922413.pdf?sequence $=1$

169. Rigotti NA, Clair C, Munafo MR, Stead LF. Interventions for smoking cessation in hospitalized patients. Cochrane Database Syst Rev. 2007;(3):CD001837. https://doi.org/10.1002/14651858.CD001837. pub2

170. Jiménez-Ruiz CA, de Granda-Orive JI, Solano Reina S, RiescoMiranda JA, de Higes-Martinez E, Pascual-Lledó JF, et al. Guidelines for the Treatment of Smoking in Hospitalized Patients. Arch Bronconeumol. 2017;53(7):387-394. https://doi.org/10.1016/j. arbr.2017.05.008

171. Rigotti NA, Clair C, Munafò MR, Stead LF. Interventions for smoking cessation in hospitalized patients. Cochrane Database Syst Rev. 2012;(5):CD001837. https://doi.org/10.1002/14651858.CD001837. pub3

172. Garcia T, Andrade SADS, Biral AT, Bertani AL, Caram LMO, Cezare $T J$, et al. Evaluation of smoking cessation treatment initiated during hospitalization in patients with heart disease or respiratory disease. J Bras Pneumol. 2018;44(1):42-48. https://doi.org/10.1590/s180637562017000000026

173. Jiménez-Ruiz CA, Andreas S, Lewis KE, Tonnesen $P$, van Schayck $C P$, Hajek $P$, et al. Statement on smoking cessation in COPD and other pulmonary diseases and in smokers with comorbidities who find it difficult to quit. Eur Respir J. 2015;46(1):61-79. https://doi. org/10.1183/09031936.00092614

174. Pederson LL, Wanklin JM, Lefcoe NM. The effects of counseling on smoking cessation among patients hospitalized with chronic obstructive pulmonary disease: a randomized clinical trial. Int J Addict. 1991;26(1):107-19. https://doi.org/10.3109/10826089109056242

175. Ladapo JA, Jaffer FA, Weinstein MC, Froelicher ES. Projected cost-effectiveness of smoking cessation interventions in patients hospitalized with myocardial infarction. Arch Intern Med. 2011;171(1):39-45. https://doi.org/10.1001/archinternmed.2010.479

176. Regan S, Reyen M, Richards AE, Lockhart AC, Liebman AK, Rigott NA. Nicotine replacement therapy use at home after use during a hospitalization. Nicotine Tob Res. 2012;14(7):885-9. https://doi. org/10.1093/ntr/ntr244 